\title{
Taxonomic revision and phylogenetic relationships of Dasyloricaria Isbrücker \& Nijssen, 1979 (Siluriformes: Loricariidae), with description of a new species
}

\author{
Alejandro Londoño-Burbano and Roberto E. Reis
}

\begin{abstract}
A taxonomic revision and phylogenetic analysis were completed for Dasyloricaria. The genus includes three valid species: D. filamentosa and D. latiura previously included in the genus, and a new species described herein. Dasyloricaria have a restricted trans-Andean distribution, with $D$. filamentosa occurring at the lower and middle Magdalena, lower Cauca, and Sinu in Colombia, and lago Maracaibo basin in Colombia and Venezuela; D. latiura in the Atrato and the Tuyra basins in Colombia and Panama, respectively; and the new species in the upper and middle Magdalena basin in Colombia. New synonyms for $D$. filamentos $a$ and $D$. latiura are proposed, and a lectotype is designated for the latter. Dasyloricaria is herein recognized as monophyletic, with $D$. filamentosa as the sister group of $D$. latiura, and the new species as sister to that clade. Spatuloricaria is hypothesized to be the sister group of Dasyloricaria based on synapomorphies of the neurocranium, branchial arches and external morphology features. The subtribe Rineloricariina was partially corroborated through the phylogenetic analysis. An identification key for the species of Dasyloricaria is provided.

Una revisión taxonómica y análisis filogenético fueron realizados para Dasyloricaria. El género incluye tres especies válidas: D. filamentosa y D. latiura previamente incluidas en el género, y una especie nueva descrita en este estudio. Dasyloricaria presenta una distribución estrictamente Transandina, con $D$. filamentosa ocurriendo en las porciones baja y media del rio Magdalena, bajo Cauca, y en el rio Sinú en Colombia, y en el lago Maracaibo en Colombia y Venezuela; D. latiura en la cuenca de los ríos Atrato y Tuyra en Colombia y Panamá, respectivamente; y la especie nueva en las porciones alta y media del rio Magdalena en Colombia. Nuevas sinonimias para D. filamentosa y D. latiura son propuestas, y el lectotipo es designado para esta última. Dasyloricaria es aquí reconocido como monofilético, con $D$. filamentosa como el grupo hermano de D. latiura, y la especie nueva como el grupo hermano de ese clado. Spatuloricaria es propuesto como el grupo hermano de Dasyloricaria, este clado está soportado por sinapomorfías del neurocráneo, arcos branquiales y características de morfología externa. La sub-tribu Rineloricariina fue parcialmente corroborada a partir del análisis filogenético. Una clave de identificación para las especies de Dasyloricaria es presentada.
\end{abstract}

Keywords: Armored catfishes, Identification key, Loricariinae, Northwestern South America, Phylogenetic analysis.

\section{Introduction}

The Loricariinae is composed by approximately 39 genera and 239 species (Eschmeyer \& Fong, 2015) distributed from the río de La Plata in Argentina to the coastal basins of the Pacific Ocean and Caribbean Sea in southern Central America (Ferraris, 2003). Species belonging to this subfamily are characterized by a long depressed caudal peduncle and the absence of an adipose fin. They are bottom dwellers and show marked variations of body shape due to the different habitats, occupying lotic to lentic systems over organic or inorganic substrates (Covain et al., 2008).

Dasyloricaria Isbrücker \& Nijssen, 1979 has a transAndean distribution in northern South America and eastern Panama. Species are currently known from the
Magdalena, Cauca, Sinú, and Atrato basins in Colombia, lago Maracaibo in Colombia and Venezuela, and in the Capeti and Tuyra basins in Panama; thus, being the only genus of the Loricariinae with a strictly trans-Andean distribution (Covain \& Fisch-Muller, 2007; Ferraris, 2003, 2007). Dasyloricaria has a relatively brief taxonomic history and has not been taxonomically revised. The genus was described by Isbrücker \& Nijssen (in Isbrücker, 1979) to include Loricaria filamentosa Steindachner, 1878, from the río Magdalena as its type species. In their description, those authors indicated that the genus was related to Spatuloricaria Schultz, 1944, "Dasyloricaria is similar to Spatuloricaria in general appearance and structure of the lips" (Isbrücker, 1979: 90; our translation). Those authors proposed a few diagnostic characters to the genus: two

PUCRS, Faculdade de Biociências, Laboratório de Sistemática de Vertebrados, P.O. Box 1429, 90619-900 Porto Alegre, RS, Brazil. (AL-B) alondonoburbano@gmail.com (corresponding author), (RER) reis@pucsr.br 
series of developed abdominal plates that cover the entire abdomen, and the presence of short, thin odontodes along the snout margin (Isbrücker, 1979: 90). In the original description of Dasyloricaria, Isbrücker \& Nijssen (1979) also transferred L. capetensis Meek \& Hildebrand, 1913, L. filamentosa latiura Eigenmann \& Vance, 1912, L. filamentosa seminuda Eigenmann \& Vance, 1912, and L. tuyrensis Meek \& Hildebrand, 1913, to the new genus.

The first proposal of a classification for Dasyloricaria within the Loricariinae was that of Isbrücker (1980). He included Dasyloricaria in the tribe Loricariini, subtribe Rineloricariina, along with Rineloricaria Bleeker, 1862, Ixinandria Isbrücker \& Nijssen, 1979, and Spatuloricaria, implying a possible close relationship among them. Covain \& Fisch-Muller (2007) offered an identification key for the Loricariinae in which only the tribes Harttiini and Loricariini were recognized and retained the relationships proposed by Isbrücker for Dasyloricaria. The authors characterized the genus by the presence of "... a secondary structure on abdominal cover consisting in double median row of plates organized in chevrons; predorsal keels strong; species of large size (generally $\geq 25 \mathrm{~cm}$ )" (Covain \& Fisch-Muller, 2007: 20). Rapp Py-Daniel (1997) conducted a morphology-based phylogenetic analysis to test the monophyly of the Loricariinae, but did not include Dasyloricaria in her osteological analysis due to scarcity of samples. Based on the examination of a single alcohol preserved specimen, she suggested that Dasyloricaria should be included within the RhadinoloricariaSpatuloricaria clade, along with Spatuloricaria and Paraloricaria Isbrücker, 1979. In a subsequent study of the Venezuelan Loricariinae, Provenzano (2011) indicated that Dasyloricaria belongs in the Loricariini, as part of a polytomy along with Pseudoloricaria Bleeker, 1862, Limatulichthys Isbrücker \& Nijssen, 1979, Loricariichthys Bleeker, 1862, Hemiodontichthys Bleeker, 1862, and Dentectus Martín Salazar, Isbrücker \& Nijssen, 1982. Alternatively, two analyses using molecular evidence that included Dasyloricaria tuyrensis (Covain et al., 2008; Rodriguez et al., 2011) and three genetic markers (one nuclear and two mitochondrial genes) indicated that the genus is sister to all Loricariini. Finally, a recent phylogenetic study by Covain et al. (2016) of the Loricariinae, including two species of Dasyloricaria (D. latiura and D.tuyrensis), found it to be the sister group of Fonchiiloricaria Rodriguez, Ortega \& Covain, 2011, this clade appearing as related to Metaloricaria Isbrücker, 1975.

More than 30 years have passed since Dasyloricaria was described, and a century since the description of the last species included in the genus. Despite those lengthy time periods, no taxonomic or phylogenetic assessments of its five species exist. Thus, the diversity and relationships within the genus and its position within the Loricariinae were unknown. The aim of this study is a taxonomic revision of the species of Dasyloricaria and a phylogenetic analysis to test its monophyly and species-level intrarrelationships.

\section{Material and Methods}

A total of 142 specimens of Dasyloricaria were analyzed. Measurements and counts follow Reis \& Pereira (2000) and Thomas \& Rapp Py-Daniel (2008), with the addition of the caudal-peduncle width which is measured at anal-fin base level, and the nares length which is measured from the anterior to posterior margins of the narial aperture. Measurements were taken point to point with digital calipers $(0.1 \mathrm{~mm}$ precision). Counts and measurements were taken from the left side of the specimens except when the structure being measured or counted was damaged, in which case the data was acquired from the right side. Counts and nomenclature of body plates follow Schaefer (1997) and Rodriguez \& Reis (2008), and tooth cusp names follow Müller \& Weber (1992). Plates covering the abdomen were separated in groups (Fig. 1) that were used for the descriptions and for the characters in the phylogenetic analysis. The lateral abdominal plates are located on the lateral region of the abdomen from the pectoral fin to the pelvic-fin origins (= thoracic plates of early authors). The median abdominal plates are located between the lateral plates from the pectoral girdle to the preanal plate (Schaefer, 1997). The medial abdominal plates are further divided into three sections: the anterior abdominal plates, which are usually smaller, irregularly shaped plates in the cleithral region; the central abdominal plates which are usually larger, more symmetrical, and located between the lateral abdominal plates; and the posterior abdominal plates which form a somewhat inflexible complex of plates between the pelvic fin bases and anteriorly border the preanal plate.

In the Comparative Material Examined section, lots are grouped as follows: catalog number, type status if appropriate, number of specimens in alcohol and cleared and stained (indicated by c\&s), country, department or state, city, river basin, collection locality and geographic coordinates. Collection dates and collector's names are provided only for types of the new species. Institutional abbreviations follow Sabaj Pérez (2012). Osteological nomenclature follows Schaefer (1987), Rapp Py-Daniel (1997) and Paixão \& Toledo-Piza (2009). Specimens for osteological observations were cleared and counterstained for bone and cartilage using the method of Taylor \& Van Dyke (1985). Specimens with excess of adipose tissue which impairs the observation of anatomical structures were soaked in Xylene to dissolve the fat (Lehmann A., 2006). Observations of the anatomical structures were made via a stereomicroscope and drawings prepared via a camera lucida.

Taxon selection for the phylogenetic analysis was based on the phylogenetic hypothesis of the Loricariinae (Rapp Py-Daniel, 1997) and taxa putatively related to Dasyloricaria (Isbrücker 1979, 1980). The outgroup was composed of Rineloricaria strigilata (Hensel, 1868), $R$. microlepidogaster (Steindachner, 1907), Spatuloricaria sp., Spatuloricaria tuira Fichberg et al., 2014, and Ixinandria steinbachi (Regan, 1906) (Rineloricariina), Loricaria 
cataphracta Linnaeus, 1758, L. clavipinna Fowler, 1940, Pseudoloricaria laeviuscula (Valenciennes, 1840), Pseudohemiodon sp., Loricariichthys anus (Valenciennes, 1836), and Hemiodontichthys acipenserinus (Kner, 1853) (Loricariini), Harttia loricariformis Steindachner, 1877, Sturisoma rostratum (Spix \& Agassiz, 1829), and S. robustum (Regan, 1904) (Harttiini). The outgroup was chosen in order to test both the relationships in Dasyloricaria and among the genera previously included in Rineloricariina sensu Isbrücker. Characters described mainly by Rapp Py-Daniel (1997), Fichberg (2008), and Paixão \& Toledo-Piza (2009) for different members of the Loricariinae were included in the analysis with additional characters proposed for the first time herein.

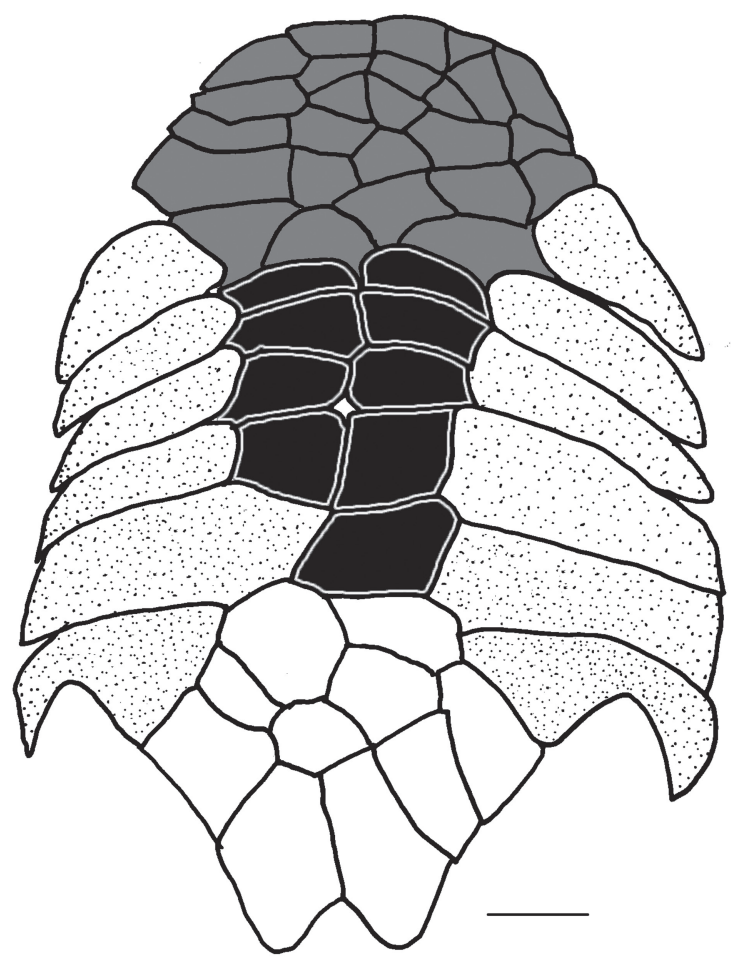

Fig. 1. Abdominal plate pattern of Dasyloricaria species. Anterior abdominal plates in gray; central abdominal plates in black; lateral abdominal plates dotted; posterior abdominal plates unpigmented.

The monophyly of Dasyloricaria, the phylogenetic relationships among its species, and the monophyly of the Rineloricariina were tested using the cladistic methodology proposed by Hennig (1966). Parsimony analysis was employed to generate hypothesis of phylogenetic relationships and character state transformations. The matrix (Appendix I) was constructed in Mesquite (Maddison \& Maddison, 2011). The phylogenetic analyses were performed using NONA (Goloboff, 1999) associated with Winclada 1.00.08 (Nixon, 2002). The heuristic search was performed with 1000 replications of Random Addition Sequence and branch swapping through the Tree Bisection Reconnection (TBR) algorithm, with additional TBR swapping to completion, on the unweighted and unordered data matrix. Cladograms were rooted on Harttia loricariformis according to previous phylogenies (Rapp Py-Daniel, 1997; Fichberg, 2008; Paixão $\&$ Toledo-Piza, 2009). Tree support was calculated in NONA as decay indices or Bremer support (Bremer, 1994).

\section{Results}

\section{Dasyloricaria Isbrücker \& Nijssen, 1979}

Dasyloricaria Isbrücker \& Nijssen, in Isbrücker, 1979: 90 (type species: Loricaria filamentosa Steindachner, 1878, by original designation; gender: female).

Diagnosis. Dasyloricaria is diagnosed by the following uniquely derived synapomorphies: (1) the metapterygoid is approximately rectangular (character 24.1); (2) the symplectic cartilage is one-half or more the length of the quadrate (character 26.2); (3) the ventrolateral process of epibranchial 4 is large and in the form of a curved shelf (character 37.2); (4) the lower pharyngeal tooth-plate is expanded, very thin and translucent (character 40.1); (5) the upper pharyngeal tooth-plate is triangular, with the anterior portion much narrower than the posterior region (character 44.2); (6) the anterior border of the cleithrum is strongly expanded anteriorly (character 54.2); (7) thick, fleshy filaments are present on upper lip anterior to the premaxillary teeth (character 66.1); and (8) the presence of a transverse bar of dark pigmentation extending over the eyes (character 73.1). Dasyloricaria can also be distinguished from other loricariines by having two rows of central abdominal plates with these sometimes separated laterally in juveniles from the lateral abdominal plates (vs. a single row of plates or plates without a clear arrangement or abdomen naked except in Loricariichthys), and the poorly papillated lips (vs. lips with filaments or papillae absent or with prominent rounded papillae).

Distribution. Dasyloricaria species inhabit the transAndean portion of northern South America and southern Central America in the Atrato, Sinú, Cauca, and Magdalena, in Colombia, lago Maracaíbo basin in Colombia and Venezuela, and the río Tuyra basin in Panama (Fig. 2).

Remarks. Dasyloricaria has several unique external and osteological features among the Loricariinae examined herein (see Diagnosis of the genus and character descriptions). One character useful to distinguish the genus, albeit not unique within the Loricariinae (shared with Loricariichthys) is the arrangement of the central abdominal plates in two rows, as previously proposed in the original description by Isbrücker \& Nijssen (in Isbrücker, 1979). Among the Rineloricariina, Dasyloricaria can be also distinguished by the incipient degree of hypertrophy of the odontodes on the lateral portions of the head of males, which are highly developed in males of Spatuloricaria, Rineloricaria and Ixinandria. 


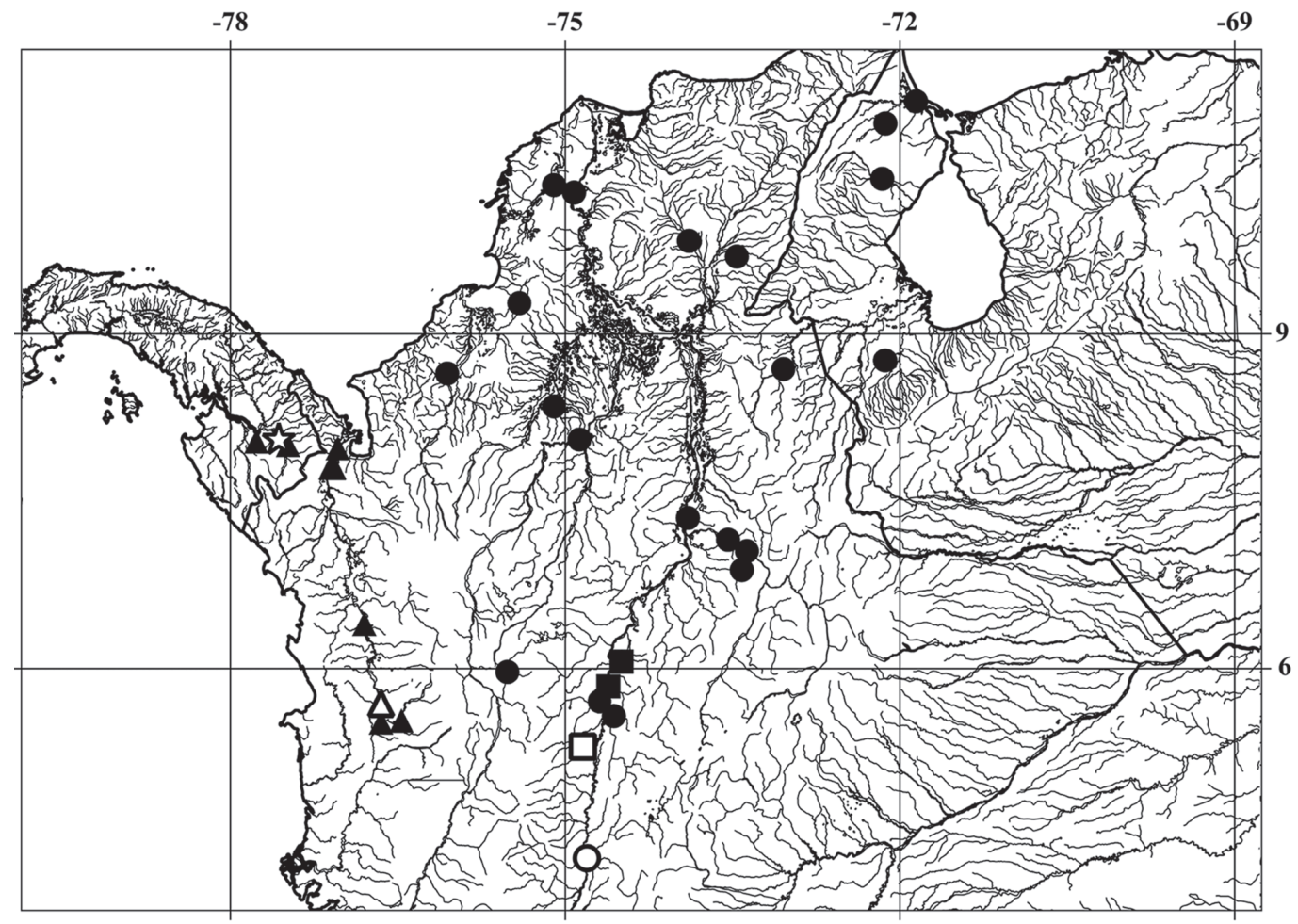

Fig. 2. Map of northwestern South America (Colombia, Panama and Venezuela) showing the distributions of species of Dasyloricaria. Black dots: Dasyloricaria filamentosa; black squares: D. paucisquama; black triangles: D. latiura; white circle: holotype of Loricaria filamentosa seminuda (= Dasyloricaria filamentosa); white square: holotype of D. paucisquama; white triangle: lectotype of Loricaria filamentosa latiura; and white star: holotype of Loricaria capetensis (= Dasyloricaria latiura) and holotype of L. tuyrensis (= Dasyloricaria latiura).

\section{Dasyloricaria filamentosa (Steindachner, 1878)}

\section{Figs. 3-4, Tables 1-2}

Loricaria filamentosa Steindachner, 1878: 45, pl. 9, fig. 1 (type locality: río Magdalena, Colombia, Lectotype NMW 44874). Eigenmann, 1920b: 30 (lower río Magdalena); 1922: 90 (description). Schultz, 1944: 328 (description; tables of measurements and counts; distributed in lago Maracaibo basin). Miles, 1947: 112; fig. 61 (brief description; lower Cauca and Magdalena; identification keys). Dahl \& Medem, 1964: 46 (brief description; río Sinú). Dahl, 1971: 92, fig. 101 (description). Galvis et al., 1997: 90 (repeat of Dahl, 1971 synonymy; brief description; Atrato, Sinú, Cauca, Magdalena, Cesar and Catatumbo basins; ventral and dorsal view photos).

Dasyloricaria filamentosa.-Isbrücker \& Nijssen, in Isbrücker 1979: 87 (description of Dasyloricaria with D. filamentosa as type species; lectotype designation). Isbrücker, 1980: 111 (composition of Dasyloricaria; species distribution; type series location); 1981: 10 (identification key for Loricariidae). Rapp Py-Daniel, 1997: 142 (brief description; assignment to Spatuloricaria-Rhadinoloricaria clade). Ferraris, 2003: 333 (genus distribution; synonymy; type material location; maximum body size). Maldonado-Ocampo et al., 2005: 134, fig. 130 (description; distribution). Villa-Navarro et al., 2006: 13 (río Magdalena). Covain \& Fisch-Muller, 2007: 4 (identification key for Loricariinae; characters of Dasyloricaria). Ferraris, 2007: 233 (synonymy; type-material depositories).

Loricaria filamentosa seminuda Eigenmann \& Vance, in Eigenmann, 1912: 13 (type locality: Girardot, Colombia, holotype FMNH 55116, NEW SYNONYM). Eigenmann, 1920b: 30 (upper río Magdalena in Colombia). Ibarra \& Stewart, 1987: 53 (holotype at $\mathrm{FMNH}$; previous $\mathrm{CM}$ number).

Loricaria seminuda.-Eigenmann, 1922: 91, pl. XIV, figs. 1 and 2 (brief description of $182 \mathrm{~mm}$ SL specimen from Girardot, Colombia). Dahl, 1971: 92 (junior synonym of Loricaria filamentosa; distribution; maximum and minimum body size; ontogeny; common names in Colombia).

Dasyloricaria seminuda.--Isbrücker \& Nijssen, in Isbrücker, 1979: 87 (description of Dasyloricaria with D. filamentosa as type species). Isbrücker, 1980: 111 (composition of Dasyloricaria; distribution; type series depositories); 1981: 10 (identification key for Loricariidae). Ferraris, 2003: 333 (genus distribution; synonymy; types location, including "FMNH 55117" as holotype of D. seminuda [that lot holotype of Loricaria fimbriata]; maximum body size; common names). Maldonado-Ocampo et al., 2005: 135 (brief description; distribution; types at FMNH and USNM). Villa-Navarro et al., 2006: 13 (río Magdalena). Covain \& Fisch-Muller, 2007: 4 (identification key for the Loricariinae; characters of Dasyloricaria). Ferraris, 2007: 234 (synonymy; location of type material, including "FMNH 55117" as holotype of $D$. seminuda [that lot holotype of Loricaria fimbriata]). 
Diagnosis. Dasyloricaria filamentosa is diagnosed by having six to eight dark transverse bars on dorsum (vs. none to four bars in D. latiura and eight in D. paucisquama). It is further distinguished from $D$. paucisquama by having seven to 12 central abdominal plates in each row (vs. four to six); and the pelvic fin always surpassing the anal-fin origin (vs. pelvic fins never reaching the anal-fin origin). Dasyloricaria filamentosa is further distinguished from D. latiura by having the anterior abdominal plates smaller than central plates (vs. same size); the anal fin with welldefined spots without forming a distal band ( $v s$. anal fin with black band on the distal portion of the rays); the black band covering the eyes never extending onto the snout (vs. the black band sometimes extending onto the snout); and the abdominal plate next to the pectoral-fin origin usually absent (vs. always present).

Description. Dorsal profile of head slightly convex to straight from snout to supraoccipital process. Dorsal profile of body slightly convex to straight from end of supraoccipital process to caudal-fin base. Plates at dorsal-fin base forming slight depression. Dorsal margin of orbit elevated; orbital notch well developed. Snout triangular in dorsal view. Odontodes poorly developed and not readily visible.

Upper lip with broad filaments that sometimes cover premaxillary teeth; short and thin filaments laterally on rictal barbel. Lower lip with filaments on posterior border similar to those on rictal barbel. Teeth slender and long in both premaxilla and dentary; number of teeth increases with ontogeny. Teeth bifid, main cusp longer and broader, almost twice as long as lateral.

Central abdominal plates always arranged in two rows in adults, without intervening spaces between them and lateral abdominal plates. Smaller plates in juveniles always arranged in two rows and with naked intervening spaces between them, lateral abdominal plates and posterior abdominal plates. Space between central and lateral abdominal plates frequently broader than single plate row of central abdominal plates. Anterior abdominal plates rounded, without regular arrangement and having naked space between anterior most plates and filaments of lower lip border.

Plates in mid-ventral and median lateral series with well-developed keels. One pair of predorsal plates between supraoccipital and nuchal plate with two well-developed keels.

Posterior margin of dorsal fin concave; its distal tip when adpressed reaching sixth to ninth plate posterior to dorsalfin base. Posterior pectoral-fin margin straight or slightly convex; spine long, reaching to or barely surpassing pelvicfin origin. Posterior pelvic-fin margin straight or slightly convex; third and fourth branched rays longest and barely reaching anal-fin origin. Distal anal-fin margin straight to rounded; second branched ray longest. Tip of anal-fin spine reaching seventh or eighth plate posterior to its base; three plates along anal-fin base. Posterior caudal-fin margin concave, upper ray extended into long filament usually as long as or longer than SL.

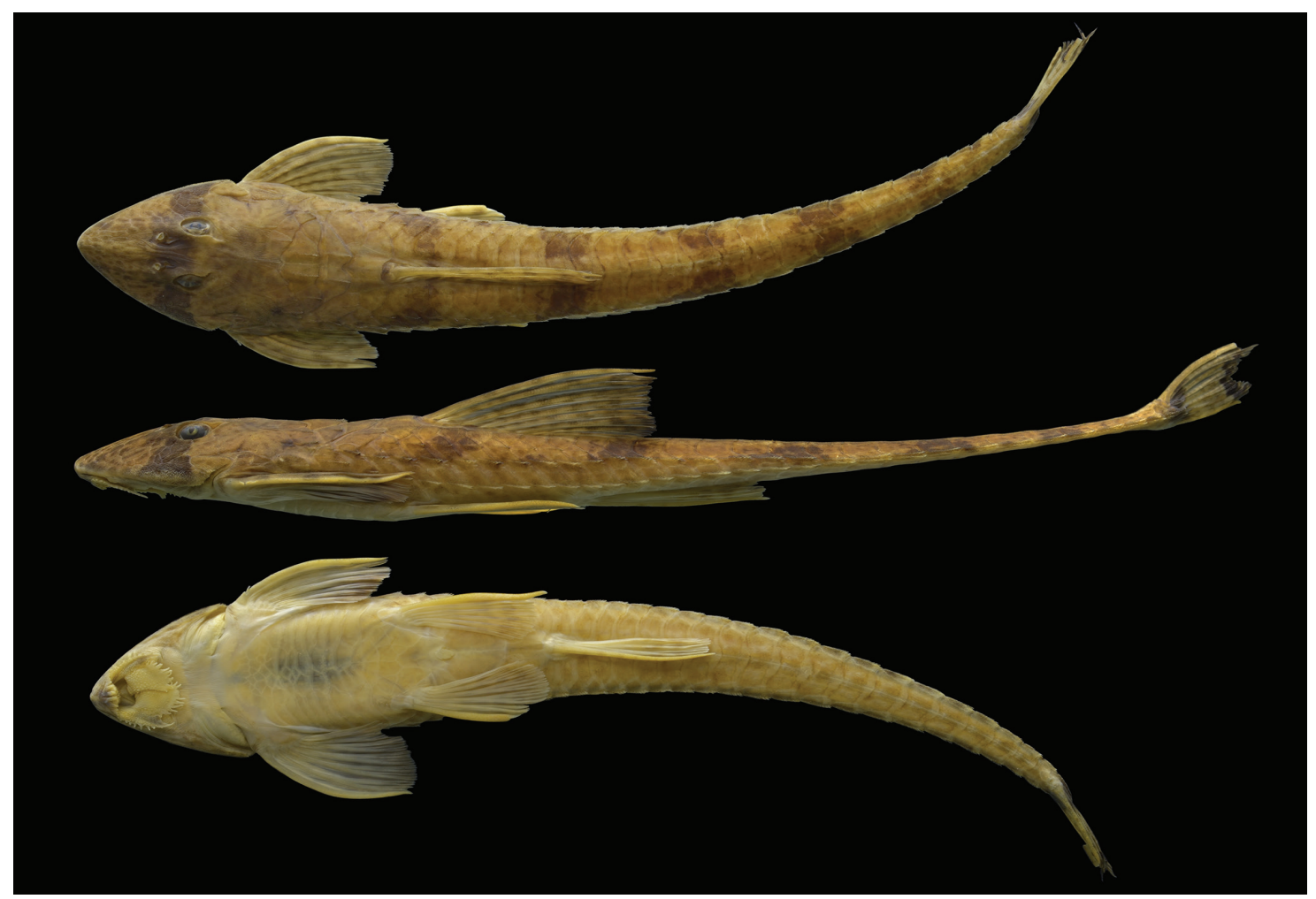

Fig. 3. Dasyloricaria filamentosa. CP-UCO 350, $192.9 \mathrm{~mm}$ SL, Colombia, Caldas Department, Norcasia, río La Miel at La Cachaza, middle Magdalena basin, 5³9’ $74^{\circ} 46^{\prime} \mathrm{W}$. 


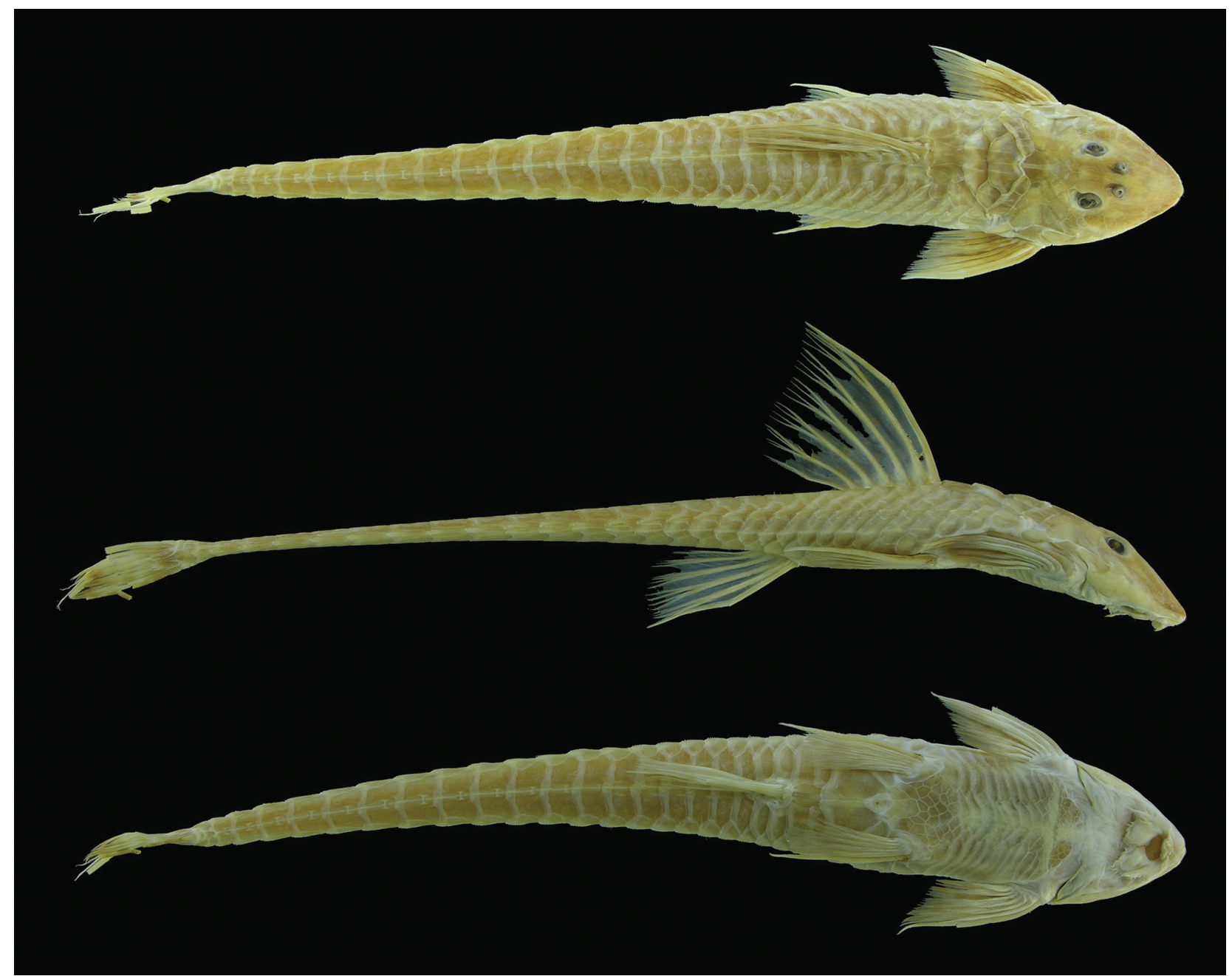

Fig. 4. Lectotype of Loricaria filamentosa. NMW 44874, $233.2 \mathrm{~mm} \mathrm{SL}$, Colombia, río Magdalena basin (exact locality unknown; photo provided by W. Helmut).

Color in alcohol. Ground color of head and trunk greyish brown dorsally; pale yellow or light brown ventrally. Upper lip filaments grey or pale yellow; upper and lower lips pale yellow. Six to eight transverse, dark, dorsal bars; first bar crossing eyes, second bar on predorsal paired plates (Fig. 3). Small and irregular black spots present on dorsal-, pectoraland pelvic-fin rays and membranes. Anal fin with scattered black spots not forming bands. Caudal-fin rays with black spots at base and complete black vertical band distally.

Sexual dimorphism. Poorly developed hyperthophied odontodes on the lateral portions of head, pectoral- and pelvic-fin spines and sometimes on the supraoccipital in males. Thickening of pectoral-fin spine was observed, associated with sexual maturity in some males. Females lack these sexually dimorphic features.

Distribution. Dasyloricaria filamentosa occurs in the lower and middle Magdalena basin, lower Cauca, and the río Sinú in Colombia, and the lago Maracaibo basin in Colombia and Venezuela (Fig. 2).
Remarks. Steindachner (1878) described Loricaria filamentosa from specimens collected in the río Magdalena, Colombia, without a precise locality. Eigenmann (1912) indicated that the specimens used by Steindachner were collected in the lower portion of the río Magdalena, but this information was not found in the NMW field records (W. Helmut, pers. com.). According to the observations herein, Eigenmann was correct concerning the distribution of $D$. filamentosa in the lower and middle portions of the río Magdalena basin (see material examined; Fig. 2).

Dahl \& Medem (1964) and Galvis et al. (1997) recorded this species in the río Sinú, Colombia, an occurrence corroborated herein. Galvis et al. (1997) and MaldonadoOcampo et al. $(2005,2006)$ reported that D. filamentosa is widely distributed in northern South America, in the Catatumbo, Magdalena, Cauca, Sinú, San Jorge, and Atrato basins, what is not confirmed here, since $D$. filamentosa is only found in the Maracaibo, Magdalena and Sinú basins.

In their original description of Loricaria filamentosa seminuda, Eigenmann \& Vance (in Eigenmann, 1912) indicated that the only difference between their subspecies 
and D. filamentosa was a naked space between the central and the lateral abdominal plates. This difference was observed in this study to reflect ontogenetic variation with the plate arrangement described for D.f. seminuda being the juvenile condition of the plates in adults of $D$. filamentosa. This was also noted by Steindachner (1878: 47), who commented "...the central rows are rudimentary in young specimens and are not in contact; in adult specimens it is not strange for them to be divided..." (our translation).

Dahl (1971), in a study of the fishes of northern Colombia, proposed D. filamentosa as a senior synonym of Loricaria fimbriata Eigenmann \& Vance, 1912, Dasyloricaria seminuda, D. latiura and D. tuyrensis. The author discussed about the few specimens used by Steindachner in the original description of $D$. filamentosa, and suggested that the five species belonged to an ontogenetic series of a single species, having collected himself the five species at the same locality. In this study we found that $D$. filamentosa is the senior synonym of $D$. seminuda, but we rejected the remaining synonyms proposed by Dahl, since $D$. latiura is a valid species with $D$. tuyrensis as its junior synonym and L. fimbriata was transferred to Spatuloricaria.

The description of Loricaria filamentosa seminuda (in Eigenmann, 1912) was based on five specimens collected at Soplaviento (CM 3804a-b and IUM 12694a-c) and a single specimen from Calamar (CM 3805); both localities in the lower Magdalena basin (Bolivar, Colombia). Those specimens were later mistakenly cataloged at FMNH as the type series of L.f. seminuda (FMNH 55113, 55114, 55116). The specimens in FMNH 55113 (CM 3804) and FMNH 55114 (CM 3805) were collected in the lower río Magdalena and identified as D. filamentosa. These were not among the specimens included in the original description of D. seminuda, and thus not types of the species. In addition, FMNH 55116 (CM 3807) is not a syntype, but the holotype of Loricaria filamentosa seminuda according to Eigenmann (1912: 13; 1922: 91), who indicated it as "type" of that species. The collection data of this specimen reads only "Girardot", a city in Cundinamarca Department, Colombia, in the upper río Magdalena. The holotype of Loricaria filamentosa seminuda is the only record of this species in the upper Magdalena, and a confirmation of its exact locality is needed.

Steindachner (1878) reported the presence of hypertrophied lower lip on mature males of $D$. filamentosa, a feature suggesting that the species is a lip brooder. That characteristic was not, however, observed on the specimens in this study. It is uncertain whether this is a function of the collection period during the year, or if the samples are composed only of females and/or non-nuptial males. Ecological studies on the species and the genus in general are lacking.

Table 1. Morphometric data for Dasyloricaria filamentosa and holotype of Loricaria filamentosa seminuda. Standard length in millimeters; holotype is included in range. HL: Head length; n: number of specimens analyzed; SD: standard deviation.

\begin{tabular}{|c|c|c|c|c|c|c|}
\hline & Holotype & $\mathrm{N}$ & Min & Max & Mean & SD \\
\hline Standard length $(\mathrm{mm})$ & 175.3 & & 101.7 & 306.7 & 204.2 & \\
\hline \multicolumn{7}{|c|}{ Percent of SL } \\
\hline Pre-dorsal length & 29.4 & 54 & 28.9 & 34.0 & 30.9 & 1.3 \\
\hline Dorsal-fin spine length & 22.5 & 54 & 19.8 & 28.2 & 23.3 & 1.6 \\
\hline Anal-fin spine length & 17.1 & 54 & 15.2 & 21.1 & 17.2 & 1.3 \\
\hline Pectoral-fin spine length & 16.7 & 54 & 15.1 & 19.0 & 16.9 & 0.9 \\
\hline Pelvic-fin spine length & 15.1 & 54 & 13.0 & 20.4 & 15.9 & 1.8 \\
\hline Lower caudal-fin ray length & 14.5 & 54 & 6.2 & 18.9 & 14.1 & 2.3 \\
\hline Head length & 20.0 & 54 & 19.5 & 23.7 & 21.7 & 1.0 \\
\hline Trunk length & 13.7 & 54 & 11.7 & 16.1 & 14.1 & 1.1 \\
\hline Abdominal length & 15.3 & 54 & 12.9 & 17.4 & 15.4 & 1.1 \\
\hline Cleithral length & 12.0 & 48 & 12.4 & 17.8 & 14.9 & 1.6 \\
\hline Body height & 9.1 & 54 & 8.2 & 11.6 & 9.6 & 0.9 \\
\hline Caudal peduncle height & 1.9 & 54 & 1.4 & 2.4 & 1.8 & 0.2 \\
\hline Post-anal length & 59.8 & 54 & 50.3 & 61.9 & 56.2 & 2.1 \\
\hline Caudal peduncle width at anal-fin base & 12.2 & 36 & 7.8 & 14.4 & 11.7 & 1.5 \\
\hline \multicolumn{7}{|c|}{ Percent of HL } \\
\hline Snout length & 54.9 & 53 & 48.3 & 59.9 & 53.8 & 2.6 \\
\hline Head height & 41.1 & 53 & 30.4 & 46.8 & 41.3 & 3.2 \\
\hline Interorbital distance & 21.1 & 54 & 17.8 & 26.0 & 21.5 & 1.7 \\
\hline Eye diameter & 14.3 & 54 & 9.6 & 16.4 & 13.3 & 1.6 \\
\hline Orbit diameter (including notch) & 23.4 & 54 & 20.2 & 27.6 & 23.1 & 1.8 \\
\hline Rostral length & 11.7 & 54 & 6.2 & 14.6 & 10.0 & 2.0 \\
\hline Nares length & 12.0 & 49 & 12.4 & 21.8 & 15.5 & 1.9 \\
\hline
\end{tabular}


Table 2. Meristic counts for Dasyloricaria filamentosa and holotype of Loricaria filamentosa seminuda. n: number of specimens analyzed.

\begin{tabular}{lccccc}
\hline Counts & Holotype & $\mathrm{n}$ & Min & Max & Mode \\
\hline Premaxillary teeth & 7 & 54 & 5 & 15 & 7 \\
Dentary teeth & 10 & 52 & 8 & 16 & 11 \\
Lateral abdominal plates & 9 & 54 & 5 & 11 & 9 \\
Plates around pre-anal plate & 3 & 54 & 3 & 5 & 3 \\
Plates at median lateral series & 19 & 54 & 16 & 21 & 18 \\
Plates at mid-ventral series & 18 & 53 & 15 & 20 & 18 \\
Coalescent plates & 12 & 53 & 10 & 15 & 13 \\
Pre-dorsal plates & 3 & 52 & 3 & 3 & 3 \\
Plates at dorsal-fin base & 5 & 54 & 4 & 6 & 5 \\
Plates at anal-fin base & 3 & 54 & 2 & 3 & 3 \\
Pectoral-fin rays & i-6 & 54 & i- 6 & i- 6 & i-6 \\
Pelvic-fin rays & i-5 & 54 & i-5 & i-5 & i-5 \\
Dorsal-fin rays & i-6 & 54 & i-6 & i-6 & i-6 \\
Anal-fin rays & i-5 & 54 & i-5 & i-5 & i-5 \\
Caudal-fin rays & i-10-i & 54 & i- $10-i$ & i- $-10-i$ & i-10-i \\
\hline
\end{tabular}

\section{Dasyloricaria latiura (Eigenmann \& Vance, 1912)}

Figs. 5-6; Tables 3-4

Loricaria filamentosa latiura Eigenmann \& Vance, in Eigenmann, 1912: 13 (type locality: Boca de Certegai, Colombia; lectotype FMNH 124472, BY PRESENT DESIGNATION). Meek \& Hildebrand, 1916: 257 (senior synonym of L. tuyrensis; description, counts and measurements; río Atrato basin, Colombia and río Tuyra, Panama). Eigenmann, 1920b: 14 (río Atrato, Colombia and río Tuyra, Panama).

Loricaria latiura. -Eigenmann, 1920a: 10 (río Atrato basin); 1922: 91, pl. XV, fig. 3 (description; as senior synonym of Loricaria tuyrense). Miles, 1947: 112; fig. 62d, f, g (brief description; as senior synonym of Loricaria tuyrense; lower río Magdalena and río Atrato, Colombia, and río Tuyra, Panama; identification key). Dahl, 1971: 92 (junior synonym of Loricaria filamentosa; distribution, ontogeny; common names in Colombia).

Dasyloricaria latiura.--Isbrücker \& Nijssen, in Isbrücker, 1979: 87 (description of Dasyloricaria with D. filamentosa as type species). Isbrücker, 1980: 111 (composition of Dasyloricaria; distribution; type series location); 1981: 10 (in identification key for Loricariidae). Ferraris, 2003: 333 (distribution; synonymy; type material depositories; maximum size; common names). Maldonado-Ocampo et al., 2006: 150 (río Atrato). Covain \& Fisch-Muller, 2007: 4 (in identification key for Loricariinae; Dasyloricaria characters). Ferraris, 2007: 233 (synonymy; type material depositories). Maldonado-Ocampo et al., 2012: 234 (lateral view photo; synonymy; description; color in alcohol; río Atrato basin; location of syntypes). Covain et al., 2016: 5 (in molecular phylogenetic analysis of the Loricariinae).

Loricaria capetensis Meek \& Hildebrand, 1913: 80 (type locality: río Capeti, río Tuyra basin, holotype FMNH 7582; NEW SYNONYM). Meek \& Hildebrand, 1916: 259, pl. XII (description; possible synonym of Loricaria filamentosa seminuda; paratype illustration in ventral view; río Capeti, Panama). Eigenmann, 1920b: 14 (río Tuyra, Panama, between Canal Zone and río Atrato). Ibarra \& Stewart, 1987: 53 (holotype number; type locality).

Dasyloricaria capetensis.-Isbrücker \& Nijssen, in Isbrücker, 1979: 87 (description of Dasyloricaria with D. filamentosa as type species). Isbrücker, 1980: 111 (composition of Dasyloricaria; distribution; type series location); 1981: 10 (in identification key for Loricariidae). Ferraris, 2003: 333 (distribution; synonymy; type material location; maximum body size; common names). Maldonado-Ocampo et al., 2006: 150 (río Atrato). Ferraris, 2007: 233 (synonymy; type material location). Maldonado-Ocampo et al., 2012: 232 (lateral view photo; synonymy; description; color in alcohol; río Atrato basin).

Loricaria tuyrensis Meek \& Hildebrand, 1913: 81 (type locality: río Tuyra basin, Panama; holotype FMNH 7583; NEW SYNONYM). Meek \& Hildebrand, 1916: 257 (as junior synonym of Loricaria filamentosa latiura). Eigenmann, 1922: 91 (as junior synonym of Loricaria latiura). Miles, 1947: 112; fig. 61 (as junior synonym of Loricaria latiura; in identification key). Dahl, 1971: 92, fig. 101 (as junior synonym of Loricaria latiura; collection localities; minimum and maximum body size; ontogeny). Ibarra \& Stewart, 1987: 54 (holotype number; number of specimens catalogued as paratypes).

Dasyloricaria tuyrensis. - Isbrücker \& Nijssen, in Isbrücker, 1979: 87 (description of Dasyloricaria with D. filamentosa as type species). Isbrücker, 1980: 112 (composition of Dasyloricaria; distribution; type series location); 1981: 10 (in identification key for Loricariidae). Ferraris, 2003: 333 (distribution; synonymy; type material location; maximum body size; common names). Ferraris, 2007: 234 (synonymy; type material depositories). Covain et al., 2008: 988 (in molecular phylogenetic analysis of the Loricariinae). Rodriguez et al., 2011: 3 (in molecular phylogenetic analysis of the Loricariinae). Covain et al., 2016: 4 (in molecular phylogenetic analysis of the Loricariinae).

Dasyloricaria filamentosa, non-Steindachner, 1878. MaldonadoOcampo et al., 2006: 150 (río Atrato; specimens actually $D$. latiura).

Diagnosis. Dasyloricaria latiura is diagnosed by the following autapomorphies: (1) the two maxillary condyles widely separated (21.2); and (2) the posterior abdominal plates larger than the central abdominal plates (character 72.1). Dasyloricaria latiura is also differentiated from congeners by the following external characteristics: none to four dorsal, transverse dark bars on the body (vs. six to eight dorsal transverse, dark bars); the presence of a black band on the distal portions of the anal-fin rays (vs. scattered black spots on anal fin not forming bands); the presence of a black bar extending over the eyes and, sometimes onto the snout (vs. black bar only extending over the eyes and never onto the snout). The species can be further differentiated from D. paucisquama by having a well-developed plate on the ventral surface next to the pectoral-fin origin (Fig. 5; vs. this plate absent). 
Description. Dorsal profile of head convex from tip of snout to supraoccipital process. Dorsal profile of body slightly convex from posterior of head to posterior of dorsal-fin base; and straight from that point to caudal-fin base. Plates along dorsal-fin base forming slight depression. Dorsal margin of orbit elevated; postorbital notch well developed. Snout triangular in dorsal view. Odontodes not well developed.

Upper lip with broad filaments that sometimes cover premaxillary teeth. Posterior border of lower lip and rictal barbel with few thin filaments. Teeth slender and long in both premaxilla and dentary; tooth number increasing ontogenetically. Teeth bifid; main cusp almost twice as long as lateral cusp.

Central abdominal plates always arranged in two rows and contacting lateral abdominal plates. Anterior abdominal plates without regular arrangement and with naked area between anterior most plates and lower lip filaments. One well developed isolated plate next to pectoral-fin origin (Fig. 5); plate not in contact with other plates.

Plates in mid-ventral and median lateral series with welldeveloped keels. One pair of predorsal plates with two welldeveloped ridges between supraoccipital and nuchal plate.

Posterior dorsal-fin margin concave; distal tip of adpressed fin reaching ninth or tenth plate posterior to dorsal-fin base. Posterior pectoral-fin margin straight or slightly convex; spine long, reaching to or surpassing pelvic-fin origin. Posterior pelvic-fin margin straight to somewhat convex; third and fourth branched rays longest and reaching anal-fin origin. Distal anal-fin margin straight or rounded; second and third branched rays longest. Tip of anal-fin spine reaching seventh or eighth plate posterior of its base. Posterior caudal-fin concave, upper ray extended into long filament, sometimes equal, but never greater than SL.

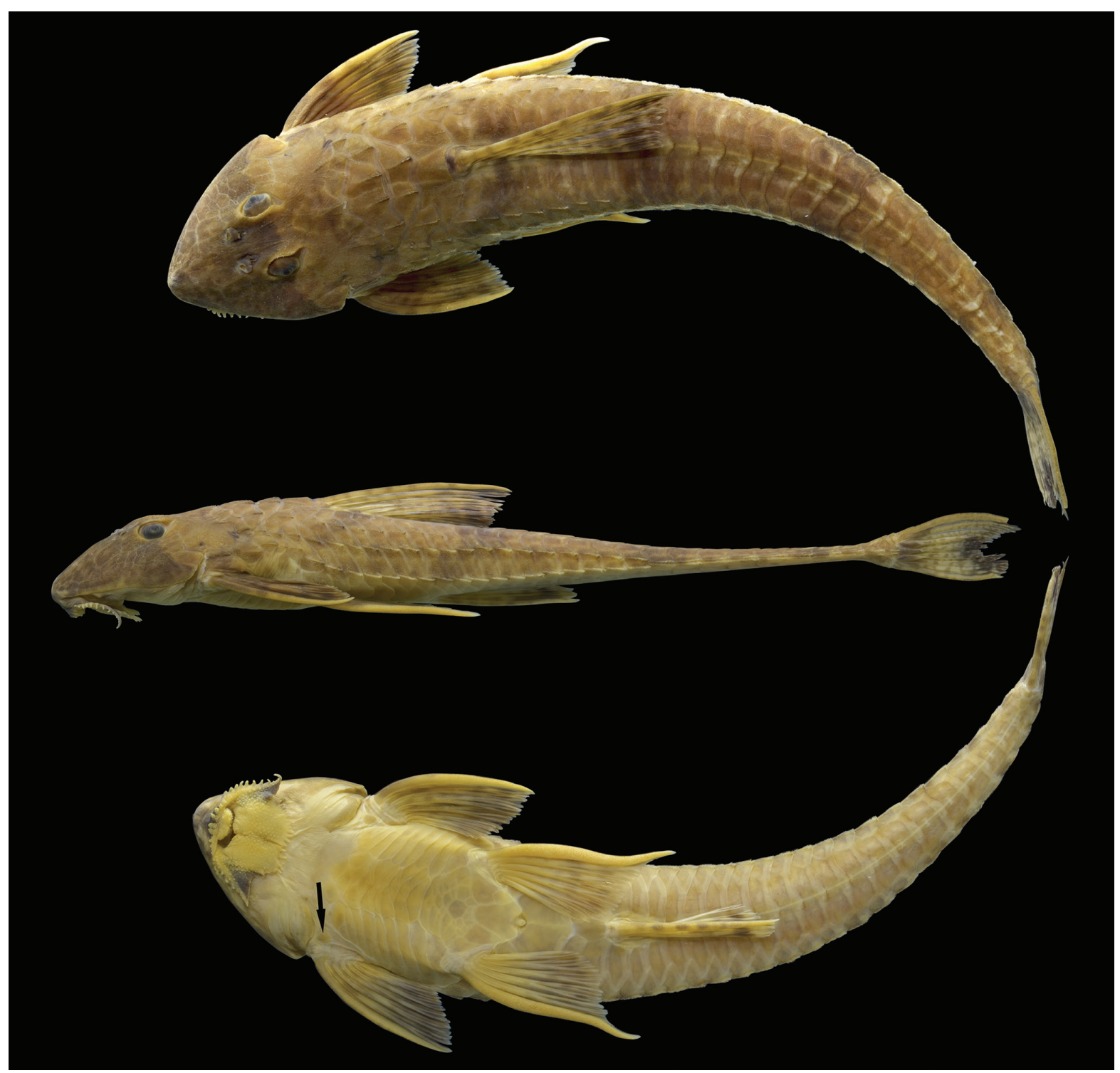

Fig. 5. Dasyloricaria latiura. IAvH-P 6777, 222.0 mm SL, Colombia, Chocó Department, río Yuto, río Atrato basin, Atlantic versant of Colombia. Arrow indicates plate next to the pectoral-fin origin. 


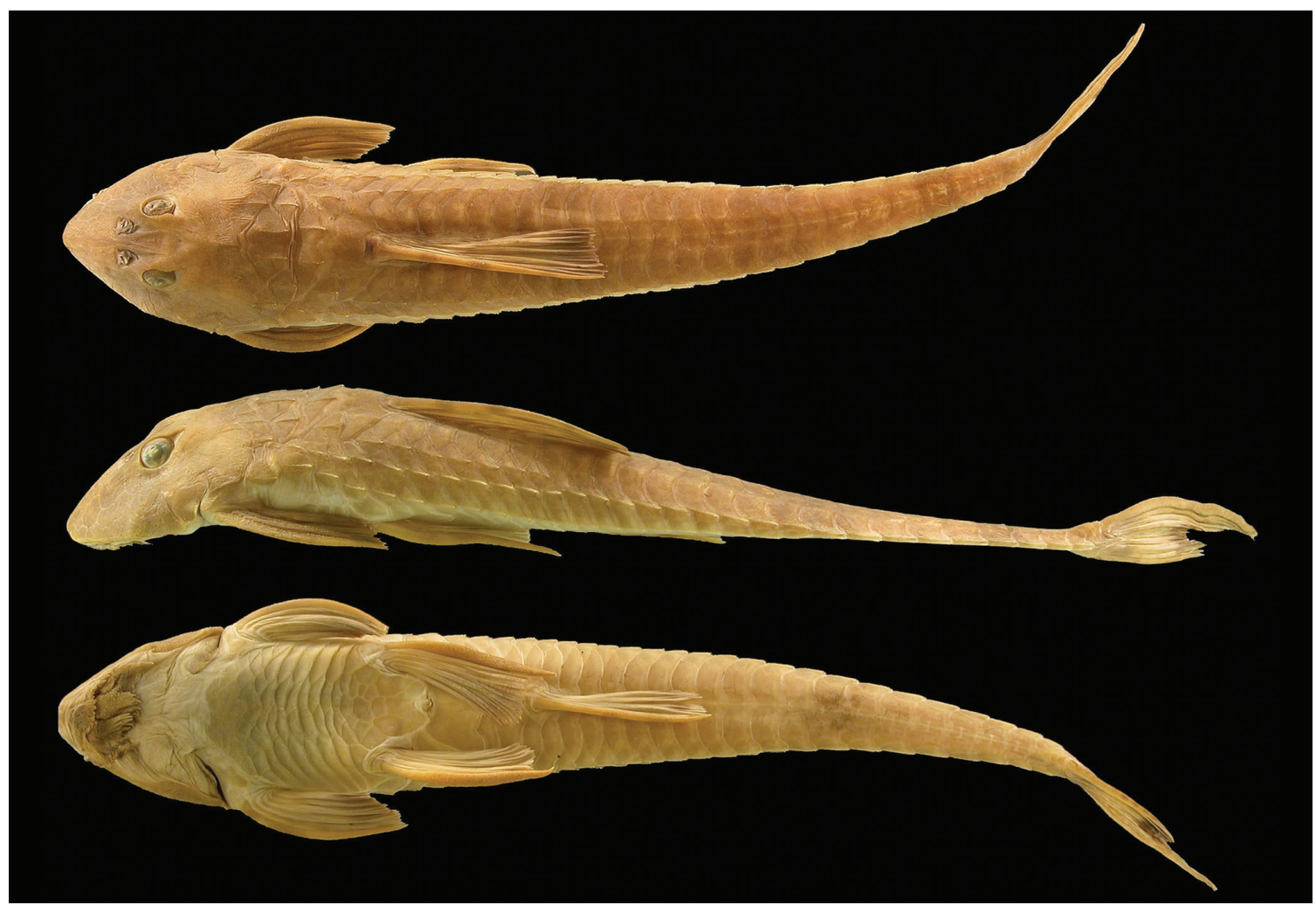

Fig. 6. Lectotype of Loricaria filamentosa latiura. FMNH 124472, 220.0 mm SL, Colombia, Boca de Certegui, río Atrato basin, Atlantic versant of Colombia (photo reproduced from FMNH website with permission of Kevin Swagel).

Table 3. Morphometric data for Dasyloricaria latiura. Standard length in millimeters; Lectotype of D. latiura included in range. A: lectotype of Loricaria latiura FMNH 124472; B: holotype of L. capetensis FMNH 7582; C: holotype of $L$. tuyrensis FMNH 7583; HL: Head length; n: number of specimens analyzed; SD: standard deviation.

\begin{tabular}{|c|c|c|c|c|c|c|c|c|}
\hline & A & B & $\mathrm{C}$ & $\mathrm{n}$ & Min & Max & Mean & SD \\
\hline Standard length $(\mathrm{mm})$ & 220.0 & 141.4 & 246.1 & & 141.4 & 287.4 & 216.6 & \\
\hline \multicolumn{9}{|c|}{ Percent of SL } \\
\hline Pre-dorsal length & 35.2 & 30.2 & 33.0 & 53 & 29.0 & 35.2 & 31.8 & 1.3 \\
\hline Dorsal-fin spine length & 24.2 & 25.9 & 23.2 & 53 & 20.5 & 26.6 & 24.1 & 1.6 \\
\hline Anal-fin spine length & 18.6 & 17.9 & 18.4 & 53 & 16.6 & 19.6 & 18.1 & 0.9 \\
\hline Pectoral-fin spine length & 17.0 & 17.5 & 16.0 & 53 & 15.7 & 18.6 & 17.0 & 0.8 \\
\hline Pelvic-fin spine length & 19.1 & 14.9 & 17.5 & 53 & 14.3 & 19.6 & 17.4 & 1.3 \\
\hline Lower caudal-fin ray length & 13.4 & 11.4 & 15.7 & 50 & 11.5 & 17.4 & 14.5 & 1.3 \\
\hline Head length & 24.2 & 21.2 & 22.9 & 53 & 20.5 & 23.9 & 22.1 & 0.9 \\
\hline Trunk length & 14.4 & 13.9 & 14.9 & 53 & 11.6 & 17.1 & 14.1 & 1.2 \\
\hline Abdominal length & 16.6 & 15.5 & 16.9 & 53 & 13.1 & 17.5 & 15.6 & 1.0 \\
\hline Cleithral length & 14.6 & 11.2 & 13.2 & 52 & 13.2 & 14.9 & 13.9 & 0.5 \\
\hline Body height & 11.1 & 8.3 & 10.1 & 53 & 8.7 & 12.4 & 10.6 & 1.0 \\
\hline Caudal peduncle height & 1.8 & 1.7 & 2.1 & 53 & 1.5 & 3.0 & 1.8 & 0.3 \\
\hline Post-anal length & 54.0 & 56.7 & 54.6 & 53 & 51.9 & 58.8 & 56.0 & 1.9 \\
\hline Caudal peduncle width at anal-fin base & 13.2 & 10.9 & 13.2 & 45 & 10.0 & 16.0 & 12.8 & 1.1 \\
\hline \multicolumn{9}{|l|}{ Percent of HL } \\
\hline Snout length & 55.5 & 53.0 & 56.6 & 53 & 43.5 & 56.5 & 54.0 & 2.3 \\
\hline Head height & 42.7 & 35.3 & 40.5 & 53 & 37.2 & 49.6 & 42.8 & 3.9 \\
\hline Interorbital distance & 22.0 & 17.3 & 22.1 & 53 & 19.0 & 23.0 & 21.3 & 1.0 \\
\hline Eye diameter & 14.7 & 14.7 & 11.3 & 53 & 11.1 & 15.7 & 13.5 & 1.3 \\
\hline Orbit diameter (including notch) & 22.1 & 25.3 & 20.2 & 53 & 20.1 & 24.9 & 22.5 & 1.2 \\
\hline Rostral length & 10.5 & 10.3 & 12.9 & 53 & 7.4 & 12.5 & 10.4 & 1.3 \\
\hline Nares length & 16.4 & 14.0 & 13.5 & 52 & 13.3 & 18.2 & 15.5 & 1.3 \\
\hline
\end{tabular}


Table 4. Meristic counts for Dasyloricaria latiura. n: number of specimens analyzed.

\begin{tabular}{lccccc}
\hline Counts & Lectotype & $\mathrm{n}$ & Min & Max & Mode \\
\hline Premaxillary teeth & 11 & 53 & 5 & 15 & 9 \\
Dentary teeth & 12 & 52 & 8 & 18 & 9 \\
Lateral abdominal plates & 8 & 52 & 6 & 9 & 8 \\
Plates around pre-anal plate & 3 & 53 & 1 & 5 & 3 \\
Plates at median lateral series & 21 & 53 & 18 & 22 & 20 \\
Plates at mid-ventral series & 20 & 53 & 18 & 22 & 20 \\
Coalescent plates & 9 & 53 & 9 & 12 & 9 \\
Pre-dorsal plates & 3 & 53 & 3 & 3 & 3 \\
Plates at dorsal-fin base & 5 & 53 & 5 & 6 & 5 \\
Plates at anal-fin base & 3 & 53 & 2 & 3 & 3 \\
Pectoral-fin rays & i-6 & 53 & i-6 & i-6 & i-6 \\
Pelvic-fin rays & i-5 & 53 & i-5 & i-5 & i-5 \\
Dorsal-fin rays & i-6 & 53 & i-6 & i-6 & i-6 \\
Anal-fin rays & i-5 & 53 & i-5 & i-5 & i-5 \\
Caudal-fin rays & i-10-i & 53 & i-10-i & i-10-i & i-10-i \\
\hline
\end{tabular}

Color in alcohol. Ground color of head and trunk greyish brown dorsally; pale yellow or light brown ventrally. Upper lip filaments grey or pale yellow; upper and lower lips pale yellow. Up to four transverse dorsal dark bars typically present but sometimes absent; first crossing eyes, second on predorsal paired plates (Fig. 5). Dorsal-, pectoral- and pelvic-fin rays and membranes with small, irregular black spots. Distal most portion of anal-fin rays with black band. Caudal fin with vertical black band along distal margin and dark basal spot.

Sexual dimorphism: Odontodes slightly hypertrophied in males along lateral portions of the head and pectoral- and pelvic-fin spines and sometimes the supraoccipital.

Distribution. Dasyloricaria latiura occurs in the río Atrato basin, on the Caribbean slope of Colombia, and in the río Tuyra basin of the Pacific versant of Panama (Fig. 2). Presence of D. latiura in both the Atrato and Tuyra basins can be explained by the Atrato River emptying into the Tuyra Gulf on the Pacific slope of Panama before the uplift of the Darien mountain range (Rodríguez-Olarte et al., 2011).

Remarks. Eigenmann \& Vance's (in Eigenmann, 1912) description of Loricaria filamentosa latiura is based on 12 syntypes from Boca de Certegui (originally CM 3806 and IU 12695). Seven specimens in CM 3806 were later recataloged as FMNH 55115 and the remaining five in IU 12695 were recataloged as CAS 13187. According to the CAS online catalog, CAS 13187 contains six specimens not indicated as types, and is composed of two original lots (IU 12695 and IU 12694), whose locality is "Soplaviento and Boca de Certegui". Boca de Certegui is in the río Atrato basin, a location within the known distribution of $D$. latiura.
Soplaviento is, however, in the lower río Magdalena, where only $D$. filamentosa is known to occur. In addition, Ferraris (2007) reports one syntype of Loricaria filamentosa latiura in USNM 79219 and mentions that the location of four syntypes is unknown. The history of the original syntypes is confusing and for this reason we herein designate a lectotype (FMNH 124472, $220 \mathrm{~mm} \mathrm{SL}$, transferred from lot FMNH 55115), in accordance with the article 74 of the International Commission on Zoological Nomenclature (ICZN, 1999).

Dasyloricaria latiura was suggested to be the senior synonym of $D$. tuyrensis by several authors (e.g. Meek \& Hildebrand, 1916; Eigenmann, 1922; Miles, 1947). Meek \& Hildebrand (1916), subsequent to their description of $D$. tuyrensis, examined the syntypes of D. latiura, and concluded they belonged to the same species. Those authors did not elaborate as to the basis for the synonymy, presenting only a brief description of $D$. latiura based on specimens collected in Panama. No diagnostic features for D. tuyrensis were found in the present study to warrant the separation of that nominal species from D. latiura. Eigenmann (1920b) suggested that $D$. latiura is present in both the Atrato and the Tuyra basins. In that same year, Eigenmann (1920a) indicated the presence of D. latiura in the Atrato, but not San Juan, a conclusion in agreement with our findings.

The holotype of Loricaria capetensis (FMNH 7582) is a juvenile that differs from adults in various features that led Meek \& Hildebrand (1913) to describe juvenile and adults as separate species (juvenile - D. capetensis; adult- $D$. tuyrensis). Both species were described from the río Tuyra, Panama. Meek \& Hildebrand (1916) redescribed their Loricaria capetensis, when they noticed its resemblance with $D$. seminuda in terms of the separation of the central and lateral abdominal plates (diagnostic character proposed for D. seminuda; see Remarks under D. filamentosa). That synonymy was not formally proposed because they did not have access to specimens of $D$. seminuda from the Magdalena basin to permit a proper comparison between populations of the Tuyra and Magdalena. This proposed synonymy is rejected in the present study.

\section{Dasyloricaria paucisquama, new species}

urn:1sid:zoobank.org:act:9D689322-8BCC-4CAB-9C3E62081835CCDC

\section{Fig. 7, Tables 5-6}

Loricaria seminuda.-Miles, 1947: 112; fig. 63 (brief description; upper río Magdalena near Honda, Colombia; identification key).

Holotype. MPUJ 6019, $203.2 \mathrm{~mm}$ SL, Colombia, Departamento de Caldas, La Dorada, La Española farm at Zona El Gigante, río Magdalena basin, río Purrio, $5^{\circ} 21^{\prime} \mathrm{N}$ 744' W, 243 masl, 30 Oct 2009, S. Prada et al. 


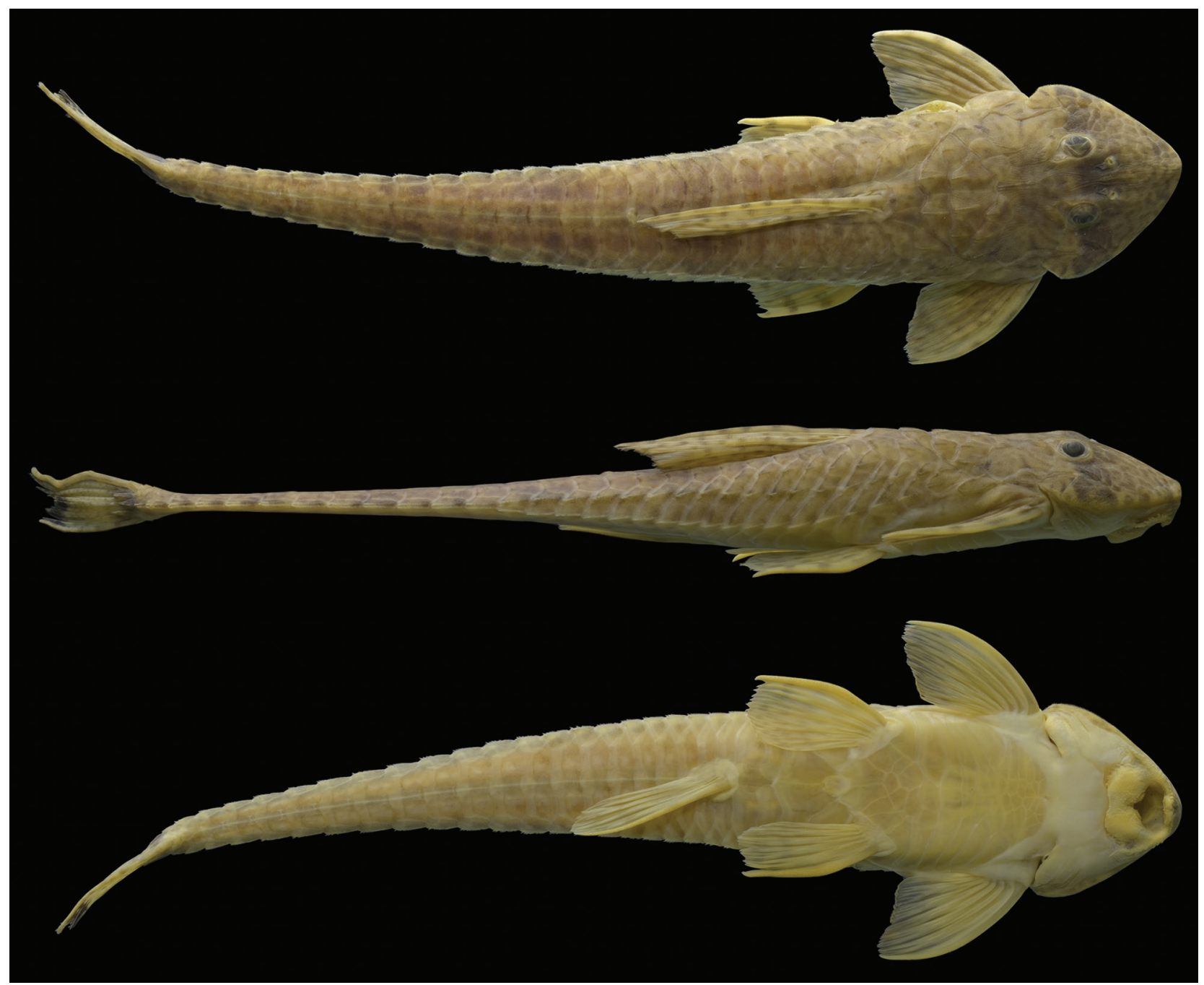

Fig. 7. Holotype of Dasyloricaria paucisquama, MPUJ 6019, $203.2 \mathrm{~mm}$ SL, Colombia, Caldas Department, La Dorada, La Española farm at Zona El Gigante, río Purrio, río Magdalena basin, 5²1 ’N 7448’ W, 243 masl.

Paratypes. Colombia: MCP 46920 (1, 179.7 mm SL), collected with holotype. CP-UCO 143 (1 c\&s, $174.3 \mathrm{~mm}$ SL) Antioquia, río Magdalena basin, southern río Samaná, tributary to río La Miel in Butantan, 541'N 7446 ' W, 189 masl, 31 Jan 2006, U. Jaramillo. IAvH-P 7683 (1, 157.7 mm SL) Boyacá, Puerto Boyacá, río Magdalena basin, Palagua and Velasquez creeks, 1 Jun 1995. MPUJ 5189 (1, 187.0 mm SL) Caldas, La Victoria, La Española farm at Zona El Gigante, río Magdalena basin, río Purrio, $5^{\circ} 22^{\prime} \mathrm{N} 74^{\circ} 47^{\prime} \mathrm{W}$, 226 masl, 25 Feb 2010, S. Prada et al. MCP 48238 (1, 157.5 mm SL) Caldas, La Dorada, Purrio, río Magdalena basin, quebrada La Rica, 5²1'N 7448'W, 259 masl, 23 Feb 2010, S. Prada et al.

Diagnosis. Dasyloricaria paucisquama is diagnosed by a single autapomorphy: the posterolateral border of the lateral ethmoid is slightly extended but does not contribute to ventral portion of the orbital rim (character 7.1). Additionally, this species can be differentiated from its congeners by having four to six central abdominal plates on each row (vs. seven to 12 plates) and a pelvic fin never reaching to the anal-fin origin (vs. pelvic fin always reaching to the anal-fin origin).

Description. Dorsal profile of head straight from tip of snout to supraoccipital process. Dorsal profile of body convex from posterior of head to beginning of dorsal-fin base, then straight from that point to caudal-fin origin. Plates at dorsal-fin base forming slight depression. Dorsal margin of orbit elevated; postorbital notch present. Head broad, its width larger than its length. Snout triangular in dorsal view, lateral borders of head broad, with welldeveloped, thin hypertrophied odontodes in adults.

Upper lip with broad filaments never covering premaxillary teeth and laterally, with short and thin filaments on rictal barbel. Posterior border of lower lip with filaments not as broad as but longer than those on upper lip. Teeth slender and long in premaxilla and dentary. Teeth bifid with, main cusp broader than and almost twice as long as lateral cusp. 
Central abdominal plates generally larger than in congeners, always arranged in two rows of 4-6 plates, with or without intervening naked spaces between them and lateral abdominal plates, but always in contact with plates bordering preanal plate; naked space never wider than one row of plates. Anterior abdominal plates irregular in size; with naked area between anterior most plates and posterior border of lower lip. Area next to pectoral-fin origin without plates. Plate in mid-ventral and median lateral series with well-developed keels. One pair of predorsal plates between supraoccipital and nuchal plate with two well-developed keels.

Posterior dorsal-fin margin straight; distal tip of adpressed fin reaching sixth plate posterior to dorsalfin base. Posterior pectoral-fin margin straight, first and second branched ray longest and reaching to or barely surpassing pelvic-fin origin. Posterior pelvic-fin margin straight to slightly convex; second and third branched rays longest but not reaching anal-fin origin. Distal anal-fin margin straight to rounded; second branched ray longest. Tip of adpressed anal fin reaching sixth plate posterior to its base. Posterior caudal-fin margin concave; filament on upper ray absent (possibly due to damage).

Table 5. Morphometric data for Dasyloricaria paucisquama. Standard length in millimeters; holotype included in range. HL: head length; n: number of specimens analyzed; SD: standard deviation.

\begin{tabular}{|c|c|c|c|c|c|c|}
\hline & Holotype & $\mathrm{n}$ & Min & Max & Mean & SD \\
\hline Standard length (SL) & 203.2 & & 157.7 & 203.2 & 176.6 & \\
\hline \multicolumn{7}{|c|}{ Percent of SL } \\
\hline Pre-dorsal length & 62.3 & 6 & 30.3 & 31.5 & 30.7 & 0.5 \\
\hline Dorsal-fin spine length & 50.4 & 6 & 19.4 & 24.8 & 21.9 & 2.4 \\
\hline Anal-fin spine length & 33.6 & 6 & 15.3 & 16.5 & 16.0 & 0.6 \\
\hline Pectoral-fin spine length & 33.5 & 6 & 15.2 & 16.9 & 16.0 & 0.9 \\
\hline Pelvic-fin spine length & 28.8 & 6 & 14.1 & 14.8 & 14.3 & 0.4 \\
\hline Lower caudal-fin ray length & 27.8 & 6 & 12.8 & 14.4 & 13.5 & 0.7 \\
\hline Head length & 41.8 & 6 & 20.6 & 21.2 & 20.8 & 0.3 \\
\hline Trunk length & 30.9 & 6 & 13.2 & 15.2 & 14.3 & 0.9 \\
\hline Abdominal length & 32.6 & 6 & 15.3 & 16.9 & 16.1 & 0.7 \\
\hline Cleithral length & 24.6 & 6 & 12.1 & 15.5 & 13.6 & 1.4 \\
\hline Body height & 22.7 & 6 & 9.5 & 11.2 & 10.5 & 0.7 \\
\hline Caudal peduncle height & 3.9 & 6 & 1.6 & 1.9 & 1.7 & 0.2 \\
\hline Post-anal length & 113.3 & 6 & 55.5 & 56.3 & 55.8 & 0.3 \\
\hline $\begin{array}{l}\text { Caudal peduncle width at } \\
\text { anal-fin base }\end{array}$ & 25.9 & 6 & 12.0 & 12.9 & 12.6 & 0.4 \\
\hline \multicolumn{7}{|c|}{ Percent of HL } \\
\hline Snout length & 22.4 & 6 & 52.7 & 53.7 & 53.4 & 0.4 \\
\hline Head height & 19.3 & 5 & 40.8 & 46.3 & 43.9 & 2.8 \\
\hline Interorbital distance & 8.9 & 6 & 20.7 & 21.8 & 21.3 & 0.4 \\
\hline Eye diameter & 6.0 & 6 & 12.2 & 14.4 & 13.8 & 1.0 \\
\hline $\begin{array}{l}\text { Orbit diameter (including } \\
\text { notch) }\end{array}$ & 9.5 & 6 & 22.7 & 23.9 & 23.5 & 0.6 \\
\hline Rostral length & 3.9 & 6 & 8.7 & 10.9 & 9.9 & 1.1 \\
\hline Nares length & 7.5 & 6 & 14.8 & 17.9 & 15.9 & 1.4 \\
\hline
\end{tabular}

Table 6. Meristic counts for Dasyloricaria paucisquama. $\mathrm{n}$ : number of specimens analyzed.

\begin{tabular}{lccccc}
\hline Counts & Holotype & $\mathrm{n}$ & Min & Max & Mode \\
\hline Premaxillary teeth & 11 & 6 & 8 & 11 & 9 \\
Dentary teeth & 12 & 6 & 9 & 13 & 11 \\
Lateral abdominal plates & 5 & 6 & 4 & 7 & 5 \\
Plates around pre-anal plate & 2 & 6 & 1 & 4 & 2 \\
Plates at median lateral series & 18 & 6 & 18 & 19 & 18 \\
Plates at mid-ventral series & 18 & 6 & 17 & 19 & 18 \\
Coalescent plates & 12 & 6 & 11 & 13 & 12 \\
Predorsal plates & 3 & 6 & 3 & 3 & 3 \\
Plates at dorsal-fin base & 5 & 6 & 5 & 5 & 5 \\
Plates at anal-fin base & 2 & 6 & 2 & 4 & 3 \\
Pectoral-fin rays & i-6 & 6 & i-6 & i-6 & i-6 \\
Pelvic-fin rays & i-5 & 6 & i-5 & i-5 & i-5 \\
Dorsal-fin rays & i-6 & 6 & i-6 & i-6 & i-6 \\
Anal-fin rays & i-5 & 6 & i-5 & i-5 & i-5 \\
Caudal-fin rays & i-10-i & 6 & i-10-i & i-10-i & i-10-i \\
\hline
\end{tabular}

Color in alcohol. Ground color of head and trunk dark greyish brown to light brown dorsally; pale yellow or light brown ventrally. Upper lip filaments grey to pale yellow; upper and lower lips pale yellow. Eight transverse, dark, dorsal bars; first crossing eyes, second on supraoccipital and predorsal plates (Fig. 7). Dorsal-, pectoral- and pelvicfin rays and membranes with small black spots. Distal most portions of anal-fin rays with diffuse dark spots. Caudal fin with longitudinal black band along tip of rays.

Sexual dimorphism. Males with slightly hypertrophied odontodes on lateral portions of head and on pectoral and pelvic fins.

Distribution. Dasyloricaria paucisquama is distributed in the upper and middle río Magdalena basin, Colombia (Fig. 2).

Etymology. Dasyloricaria paucisquama is named from the Latin paucis, meaning few, little and squama, meaning scale or plate, in allusion to the smaller number of central abdominal plates typical of this species. A noun in apposition.

Conservation status. Although with scarce lots, current plausible threats to the species were not detected in its distribution area, therefore Dasyloricaria paucisquama could be classified as Least Concern (LC), according to the International Union for Conservation of Nature (IUCN) categories and criteria (IUCN Standards and Petitions Subcommittee, 2014).

Remarks. Dasyloricaria paucisquama and D. filamentosa are sympatric in the middle río Magdalena, but not in the upper portions of that basin. The only record of $D$. filamentosa from the upper Magdalena is the holotype of D. seminuda, described from a locality only recorded as "Girardot" and which may be an error, since no further 
specimens of $D$. filamentosa were collected in the upper Magdalena. In addition, the record of Miles (1947) of $D$. seminuda near Honda and Huila Department, both part of the upper Magdalena basin, is here regarded as Dasyloricaria paucisquama based on the locality and the drawings in that publication.

\section{Identification key for the species of Dasyloricaria}

1. Four to six central abdominal plates in each row; plates well developed and usually lacking intervening naked spaces except in juveniles; pelvic fin not reaching analfin origin. Dasyloricaria paucisquama (Upper and middle río Magdalena basin)

1'. Seven to 12 central abdominal plates in each row, sometimes with intervening naked spaces between themselves and between them and the lateral abdominal plates; pelvic fin always surpassing the anal-fin origin.......2

2. None to four dark, transverse bars on dorsum; anterior abdominal plates similar in size to central plates; anal fin with vertical black band on distal portion of rays; black band covering eyes sometimes extended onto snout; conspicuous plate present ventrally next to pectoral-fin origin Dasyloricaria latiura

(Río Atrato and río Tuyra basins)

2'. Six to eight dark, transverse bars on dorsum; anterior abdominal plates smaller than central plates; anal fin with well-defined spots without forming distal band; black band covering eyes never extending onto snout; plate usually lacking next to pectoral-fin origin ....

..Dasyloricaria filamentosa

(Río Magdalena and río Sinu, and lago Maracaibo basin)

\section{Phylogenetic relationships}

The characters descriptions are grouped by anatomical units.

Neurocranium. 1. Shape of the mesethmoid disk (Schaefer, 1987). The ventral mesethmoid disk of loricariids is circular in lateral view, robust and with edges thicker than central portion (Schaefer, 1987; state $0)$. In some species the mesethmoid disk is laminar but conspicuous and disk-like in lateral view (state 1), or laminar but rectangular or triangular in lateral view (state 2).

2. Development of the lateral expansion of the mesethmoid. The variably developed lateral expansion of the mesethmoid articulates synchrondrally with the lateral ethmoid. It can be inconspicuous, approximately one-half the width of the vomer (state 0 ), or approximately the width of vomer (state 1; Fig. 8).
3. Ventral concavity on anterior tip of mesethmoid (Schaefer, 1990). Schaefer (1990) first described a ventral concavity on the anterior tip of the mesethmoid in scoloplacids. The ventral concavity of the mesethmoid is present in a few species (state 1) but absent in most (state 0; Fig. 8).

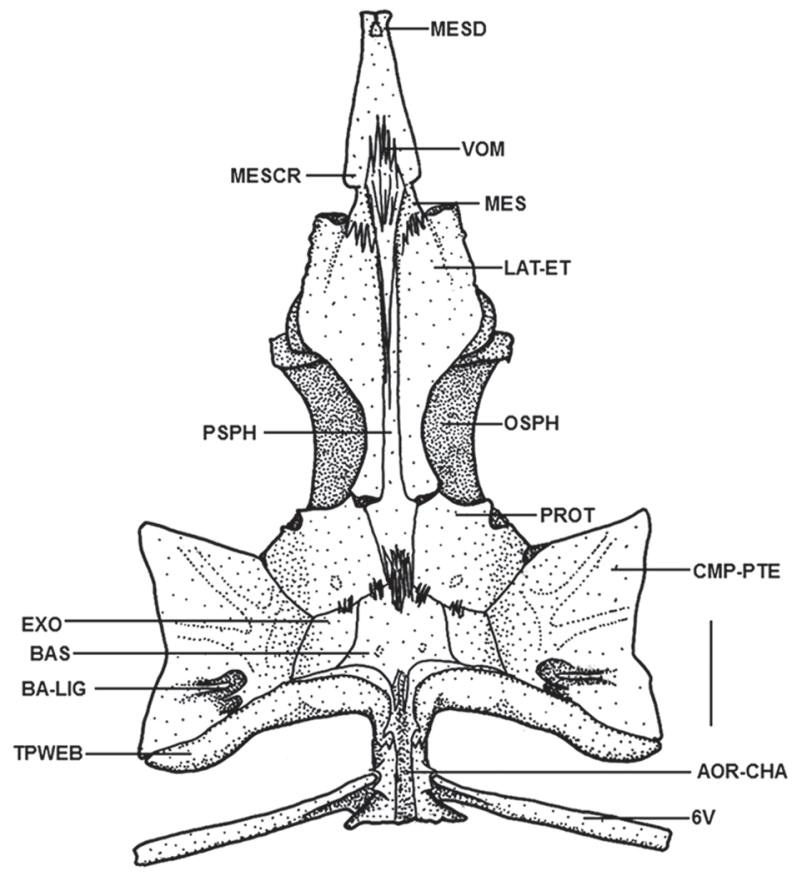

Fig. 8. Ventral view of neurocranium of Dasyloricaria paucisquama, CP-UCO 143. MESD: mesethmoid disc; VOM: vomer; MESCR: mesethmoid crest; MES: mesethmoid; LAT-ET: lateral ethmoid; PSPH: parasphenoid; OSPH: orbitosphenoid; PROT: prootic; CMP-PTE: compound pterotic; EXO: exoccipital; BAS: basioccipital; BA-LIG: Baudelot's ligament; TPWEB: transverse process of Weberian apparatus; AOR-CHA: aortic cannel; 6V: sixth vertebra. Scale bar $=5 \mathrm{~mm}$.

4. Extension of the naked area on the snout tip. Among the examined groups, the Harttiini have an elliptical, naked area on the snout tip that does not reach the last sensory pore (state 0). In other species, the naked area on the snout tip can be elliptical or elongate and reaches the last pore of the infraorbital sensory canal (state 1). Dasyloricaria and most of the Loricariini possess a roundish naked area that does not reach the last sensory pore (state 2). Finally, Loricariichthys and Pseudohemiodon have the snout tip completely covered with dermal plates without a naked area (state 3 ).

5. Shape of the parasphenoid (Schaefer, 1991). The parasphenoid of loricariids is generally narrow along its entire length (Schaefer, 1987, 1991; Rapp Py-Daniel, 1997; Armbruster, 2004; Lehmann A., 2006; Pereira, 2008), as observed in Dasyloricaria paucisquama (state 0). Alternatively, the parasphenoid of Sturisoma, D. latiura and D. filamentosa is broad posteriorly at its area of articulation with the basioccipital (state 1). 
6. Dorsolateral process of the lateral ethmoid (Schaefer, 1987). Dorsolateral processes of the lateral ethmoid are barlike projections in the Harttiini and some other taxa (state 0 ). The projections are shaped as large wings, which contribute to the orbital rim and can extend a little beyond the orbital rim in Dasyloricaria paucisquama and some other taxa (state 1; Fig. 8). Finally, in some species the dorsolateral process of the lateral ethmoid is reduced (state 2).

7. Posteroventral border of the lateral ethmoid (Howes, 1983). The posteroventral border of the lateral ethmoid can be simple and match the anterior orbital rim (state 0). Alternatively, it can be slightly extended but still not contribute to the ventral portion of the orbital rim (state 1) or distinctly extended and contribute to the ventral portion of the orbital rim (state 2).

8. Lateral process of the sphenotic (Schaefer, 1987). The sphenotic process has been subject of discussions regarding its homology with the lateral spine of other Siluriformes. Schaefer (1987) proposed that homology contra the hypothesis of Howes (1983) who hypothesized that the lateral spine is absent in most siluriforms. The lateral process of the sphenotic can be short, never reaching one-half of the sphenotic height (state 0), about one-half the height of the bone (state 1), or still very long process, similar to the height of the sphenotic (state 2; Fig. 9) as in Dasyloricaria and Spatuloricaria. Conversely, in some species the lateral process is much reduced or absent (state 3 ).

9. Postorbital notch (Fichberg, 2008, character 163, modified). The postorbital notch is a feature found only in some Loricariini among loricariids. We followed Fichberg (2008) and considered the notch as short when it was less than one-half the orbital length (state 1), and long when it is at one-least half the orbital length (state 2; Fig. 9). The postorbital notch is absent in other loricariids (state 0 ).

10. Ornamentation of theparieto-supraoccipitaland predorsal plates. Loricariines commonly have a marked development of odontodes crests on the parieto-supraoccipital and predorsal plates. Such crests can be absent (state 0) and when present their degree of development is quite variable among loricariids. Crests can be low and poorly developed (state 1), or well developed and conspicuous (state 2; Figs. 3,5,7), as in Dasyloricaria and Hemiodontichthys.

11. Lateral processes of the basioccipital (Schaefer, 1990). The basioccipital of loricariids has lateral processes with a wide variation in orientation and size. These lateral processes (described as dorsal processes by Schaefer, 1990) synchondrally articulate to the prootic. Such processes can be expanded not only laterally but also ventrally (state 0 ), or laterally expanded and as, or almost as, long as the occipital (state 1), or highly laterally expanded passing the exoccipital (state 2; Fig. 8). Conversely, the processes can be short and not reaching beyond one-half of the exoccipital (state 3 ).
Cephalic sensorial canals. 12. Ventral process of preopercle (Rapp Py-Daniel, 1997, Character 53). The ventral process of the preopercle along the posterior margin of that bone was described by Rapp Py-Daniel (1997) and contacts a bony plate (the subpreopercle of Rapp Py-Daniel, 1997; and the canal-bearing plate of Schaefer, 1991). Such a process is present in the Harttiini (state 0 ) but absent in the remaining Loricariinae (state 1; Figs. 10a-c).

13. Shape of the nasal (Rapp Py-Daniel, 1997: 171, modified). The nasal bone located anterior to the frontal and mesial to the nostril includes the terminus of the supraorbital sensory canal. All of the Loricariini except Ixinandria have a long, slim nasal (state 1; Fig. 9); whereas the Harttiini and Ixinandria share a short, broad, more square nasal (state 0 ).

14. Extension of the nasal sensorial canal (Rapp Py-Daniel, 1997; Character 170, modified). The supraorbital sensory canal usually ends in the nasal (state 0 ). In a few loricariids, however, the canal continues as a small tube into a dermal plate immediately anterior to the nasal (state 1; Fig. 9).

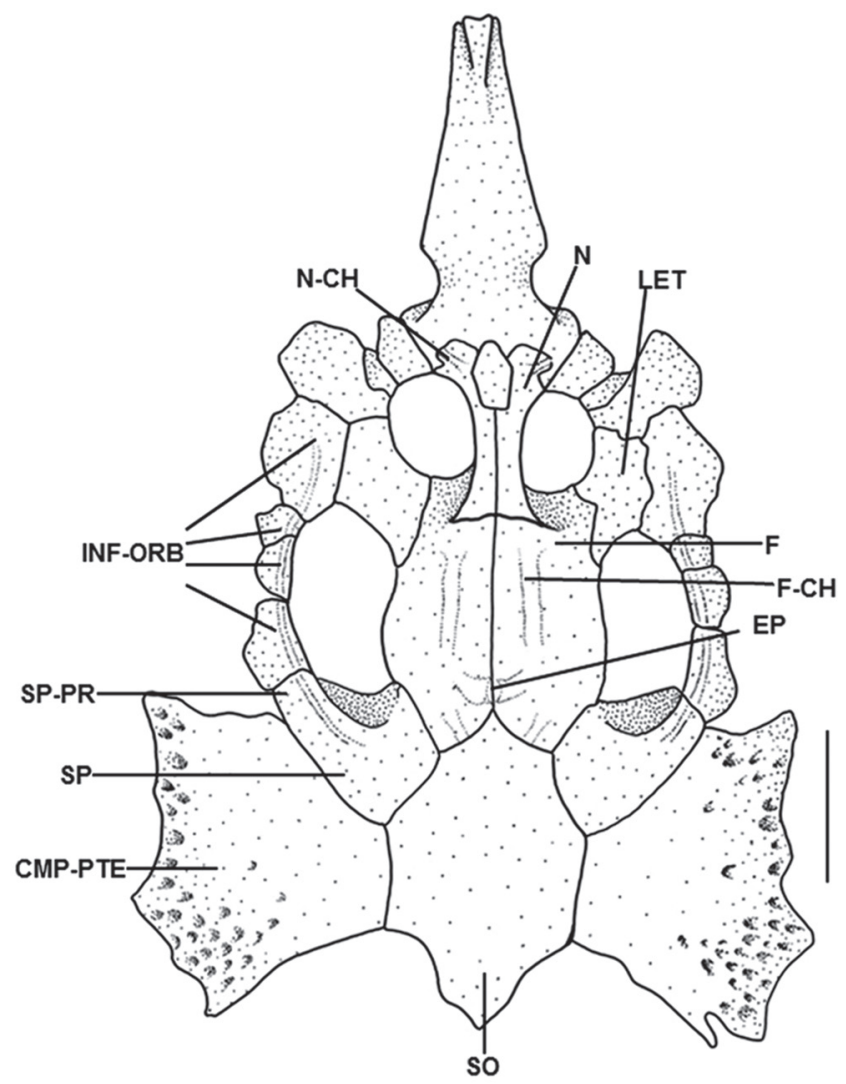

Fig. 9. Dorsal view of neurocranium of Dasyloricaria paucisquama, CP-UCO 143. N: nasal bone; N-CH: nasal channel; LET: lateral ethmoid; F: frontal; F-CH: frontal channel; EP: epiphyseal pore; INF-ORB: infraorbitals (including channel); SP-PR: sphenotic process; SP: sphenotic; CMP-PTE: compound pterotic; SO: supraoccipital. Scale bar $=5 \mathrm{~mm}$ 


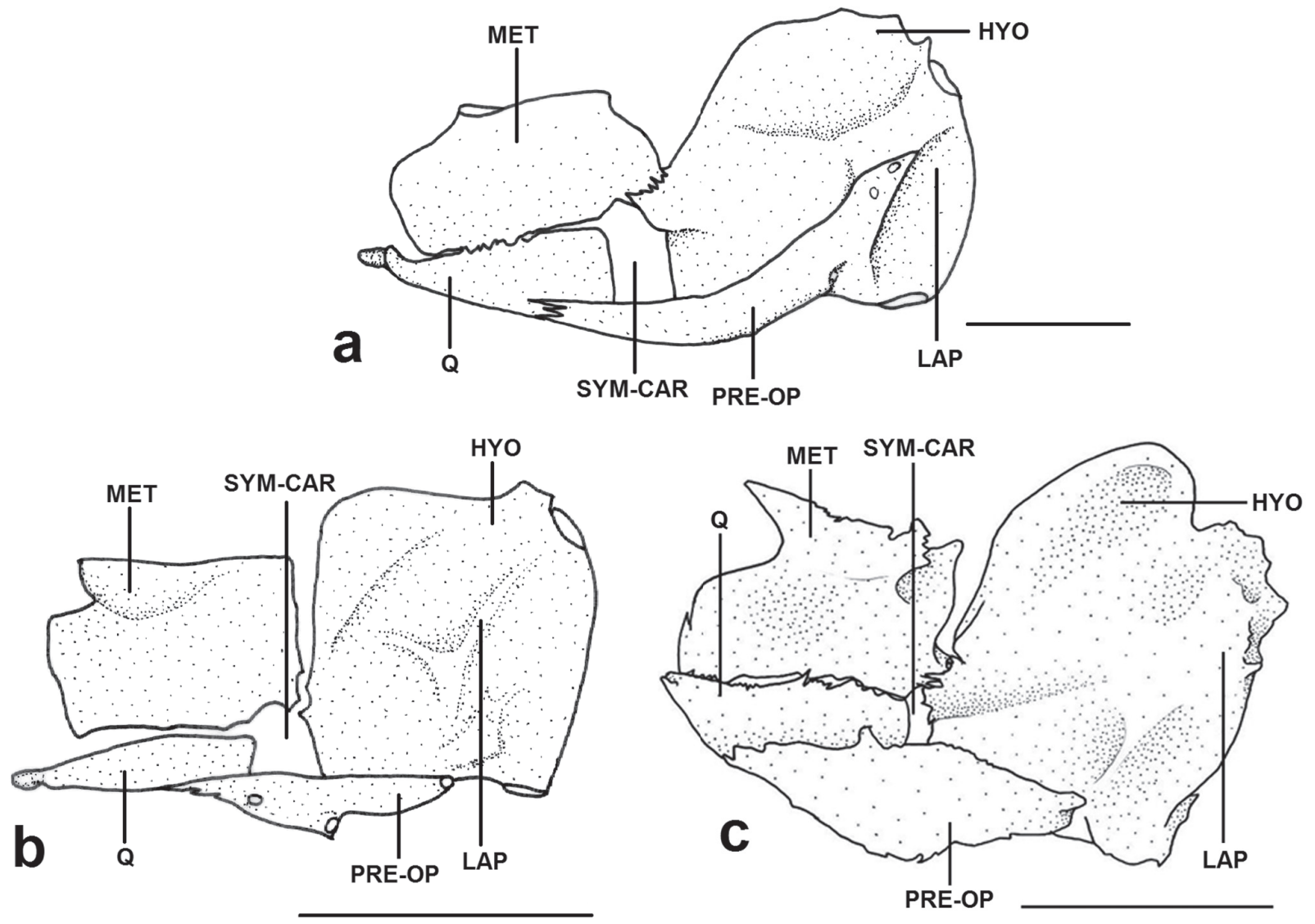

Fig. 10. Lateral view of suspensorium of: a. Dasyloricaria paucisquama, CP-UCO 143; b. Spatuloricaria sp., MCP 15806; c. Pseudohemiodon sp., MCP 36577. HYO: hyomandibula; LAP-MCRT: levator arcus palatini muscle crest; PRE-OP: preopercle; Q: quadrate; MET: metapterygoid; SYM-CAR: symplectic cartilage. Scale bar $=5 \mathrm{~mm}$.

15. Terminus of the parietal branch of the supraorbital sensory canal (Schaefer, 1987). The parietal branch of the supraorbital canal of Hypostomus plecostomus has its terminal pore in the sphenotic (Schaefer, 1987), but varies significantly in position among examined loricariids. In Harttia, the terminal pore is in the sphenotic (state 0). In other groups the terminal pore can be at the articulation between the frontal and the supraoccipital (state 1); between the frontal and the sphenotic (state 2); on the supraoccipital (state 3); or on the frontal (state 4; Fig. 9).

16. Shape of the epiphyseal pore of the supraorbital sensory canal (Schaefer, 1987). The epiphyseal pore of the supraorbital sensory canal of most loricariids (Fig. 9) is usually large and readily visible between the frontals (state 1). Alternatively, the epiphyseal pore can be reduced in size (state 0) or form a groove as in Dasyloricaria and some loricariines (state 2).

Jaws and autopalatine. 17. Shape of the autopalatine (Arratia, 1990). The autopalatine is generally a rod-shaped bone connecting the lateral ethmoid to the upper jaw; sometimes with ventrolateral or dorsolateral expansions (Arratia, 1990, Figs. 11a-c). Studied loricariids vary in the shape of the autopalatine. In Harttia the autopalatine is simple, rod-shaped and lacks expansions (state 0, Fig. 11c). Alternatively, in Dasyloricaria and other taxa the autopalatine has expansions extending two-thirds of the bone (state 1; Fig. 11a), or the expansions can extend along the entire length of the bone (state 2). Finally, the autopalatine can be curved and bear a small lateral expansion (state 3, Fig. 11b).

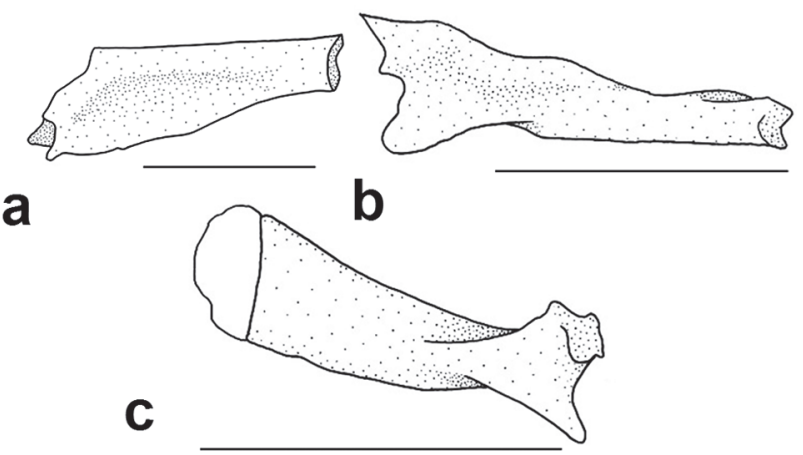

Fig. 11. Lateral view of autopalatine of: a. Dasyloricaria paucisquama, CP-UCO 143; b. Loricaria cataphracta, MCP 41395; c. Harttia loricariformis, MCP 11707. Scale bar $=5 \mathrm{~mm}$. 
18. Autopalatine splint (Schaefer, 1987). The autopalatine of most loricariids bears a thin, approximately straight, sesamoid ossification that extends parallel to the autopalatine from the anterior palatine cartilage to the nasal opening and the lateral ethmoid (state 0 ). Conversely, the splint is absent in the Loricariini (state 1).

19. Shape of the premaxilla (Schaefer, 1987). The premaxillae of loricariids are loosely attached to the mesethmoid and highly mobile (Schaefer \& Lauder, 1986). The variation in shape is notable with the premaxilla being long and rectangular, thick, and tridimensional (state 0); quadrangular, thick, and strongly tridimensional (state 1); slim and elongate (state 2); or very thin and reduced to a lamina (state 3).

20. Length of the premaxilla. The length of the premaxilla is variable among examined loricariids. The premaxilla can be long and approximately equal to or slightly longer than the autopalatine (state 0 ); or short and approximately onehalf the length of the autopalatine (state 1), or very short and measuring one-fourth the length of the autopalatine (state 2).

21. Shape of the maxilla (Rapp Py-Daniel, 1997; Character 29 , modified). The maxilla of loricariids is connected to the autopalatine via one or two condyles (Rapp Py-Daniel, 1997). Among the examined taxa the maxilla has one condyle (state 0 ), two closely positioned condyles (state 1; Figs. 12b,c) or two more widely separated condyles (state 2; Fig. 12a).

22. Size of the dentigerous area of the dentary (Schaefer, 1987). As is the case with the premaxilla, the dentary has a cup-shaped concavity where the teeth are implanted. In some loricariids the dentigerous area is almost as long as the dentary itself (state 0 ). Conversely, in most of the Loricariini the dentigerous area is shorter and never occupies the entire length of the bone (state 1). Finally, in Hemiodontichthys and Pseudohemiodon the tooth-bearing concavity is much reduced or absent (state 2).

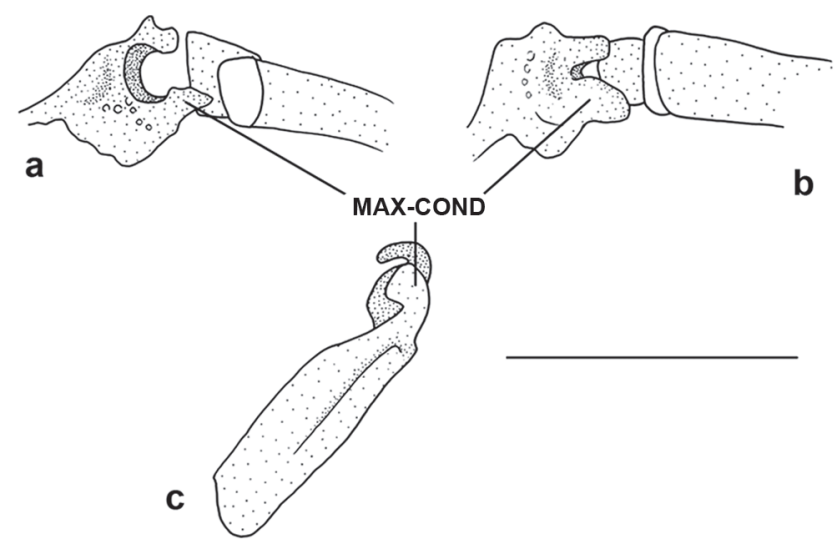

Fig. 12. Dorsal view of maxillary bone of: a. Dasyloricaria paucisquama, CP-UCO 143; b. D. latiura, USNM 293296; and lateral view: c. Dasyloricaria paucisquama, CP-UCO 143. MAX-COND: maxillary condyles. Scale bar $=5 \mathrm{~mm}$.
Suspensorium. The suspensorium of Loricariidae is composed by the hyomandibula, metapterygoid, quadrate and preopercle (Schaefer, 1987; Arratia, 1990; Figs. 10a-c), with the ectopterygoid and endopterygoid being absent in the family (Rapp Py-Daniel, 1997). Arratia (1990) discusses the possible homologies of the metapterygoid and the absence of the endopterygoid and ectopterygoid. Despite the absence of the latter bones in loricarioids and the several studies across the Siluriformes (Howes, 1983; Schaefer \& Lauder, 1986; Schaefer, 1987; Arratia, 1987, 1990; Mo, 1991) there is no consensus on the homology of the pterygoid bones of loricarioids. Diogo et al. (2001) suggest that the real metapterygoid is fused to the hyomandibula, and that what is usually called metapterygoid is a dermal bone homologous to the ectopterygoid and endopterygoid of other fishes. We follow Schaefer (1987) and Arratia (1990) in interpreting a metapterygoid separate from the hyomandibula.

23. Canal of the metapterygoid (Howes, 1983). The metapterygoid of loricariids contacts the hyomandibula posteriorly and the quadrate ventrally (Figs. 10a-c). A feature first noted by Howes (1983) and later by Schaefer (1987) is the presence of a metapterygoid canal. This canal is formed by a lateral, laminar wall of the metapterygoid, which contacts the mesethmoid dorsally thereby forming a closed or partially closed canal. In some species the canal is deep and completely covered by the lateral laminar wall (state 0 ). In other species, the canal is deep but not completely covered by the lateral wall (state 1). Alternatively, a shallow but noticeable canal occurs in some members of the Loricariini (state 2) or the canal is absent or inconspicuous as in Dasyloricaria (state 3).

24. Shape of the metapterygoid. The metapterygoid of Dasyloricaria has a characteristic shape, being roughly rectangular because of a posterior expansion that articulates by means of an interdigitated suture to the hyomandibula. Consequently, the dorsal portions of these bones are widely separated and lack further contact (state 1; Fig. 10a). In other examined loricariines the hyomandibula is approximately quadrangular and although also articulated to the hyomandibula, is not expanded posteriorly and the dorsal portions of the bones are not widely separated (state 0; Figs. 10b,c).

25. Crest for attachment of the levator arcus palatini onto the hyomandibula (Schaefer, 1987). The hyomandibula of loricariids usually has a conspicuous crest for the insertion of the levator arcus palatini, which usually occupies more than one-half the length of the bone (state 0; Fig. 10a). In a few taxa the crest is reduced and shorter than one-half the length of the bone (Schaefer, 1991; state 1).

26. Size of the symplectic cartilage. The symplectic cartilage (sensu Arratia, 1990) is located in the middle of the suspensorium, between the metapterygoid, 
hyomandibula and quadrate. The cartilage varies, ranging from reduced, almost one-eighth of the length of the quadrate (state 0 ), of approximately one-fourth the length of the quadrate (state 1, Fig. 10c), or one-half or more of the length of the quadrate (state 2; Figs. 10a,b).

27. Depth of the quadrate (Arratia, 1990). The quadrate of the loricariids ranges in form. In some taxa, its depth reaches at least one-half the depth of the hyomandibula (state 0 ), or alternatively, its depth is distinctly less than one-half the depth of the hyomandibula (state 1; Fig. 10).

28. Shape of the preopercle (Rapp Py-Daniel, 1997, Character 50; modified). The generalized shape of the preopercle of loricariids was described by Rapp Py-Daniel (1997) as thin and slender (state 1), but in some members of the group is wide and robust (state 0 ). In the present study, we corroborate those observations and found that a thin, slender preopercle is a non-exclusive synapomorphy of the Loricariini.

29. Shape of the sensory canal of the preopercle (Rapp PyDaniel, 1997, Character 54; modified). The sensory canal of the preopercle of Harttia and Pseudohemiodon has a curved form (state 0). A straight tube was alternatively observed in most examined taxa (state 1).

Hyoid and branchial arches. The hyoid arch is composed of the paired anterohyals, posterohyals, branchiostegal rays, hypohyals, and the unpaired urohyal. The dorsal hypohyals are absent in loricariids but present in callichthyids (Reis, 1998) among loricarioids. The branchial arches are composed of two unpaired hypobranchials and the paired elements: three basibranchials, five ceratobranchials, four epibranchials, and two pharyngobranchials.

30. Relative length of laminar expansion along the ventral border of anterohyal (Paixão \& Toledo-Piza, 2009; Character 10, modified). Paixão \& Toledo-Piza (2009) described three states for this character. In the plesiomorphic state the laminar expansion along the ventral border of the anterohyal flares abruptly and is restricted to the lateral portion of the bone (state 0 ). In other taxa the laminar expansion begins gradually in the middle of the anterohyal and expands towards the lateral portion of the bone, but is only slightly developed (state 1). Finally the laminar expansion can commence gradually in the middle of the anterohyal and expand towards the lateral portion and is wide and well developed (state 2).

31. Projection of urohyal processes through the hypohyal foramina. The urohyal possesses two anterior projections with different degrees of development among the taxa studied. These processes can be medium-sized, just crossing the foramina (state 0), or they can be short and not cross the hypohyal foramina (state 1).
32. Shape of basibranchial 3 (Rapp Py-Daniel, 1997; Character 67, modified). Basibranchial 1 is absent in loricariids while basibranchial 2 (thus, the first in the series) is always ossified. Basibranchial 3 is ossified in loricariines and some hypostomines, and cartilaginous in most other loricariids, while the basibranchial 4 is variably present and always cartilaginous (Pereira, 2008). Among the taxa examined, basibranchials 3 (the second basibranchials of Rapp Py-Daniel, 1997) were always ossified while basibranchial 4 was always present and cartilaginous. Basibranchial 3 can have the shape of a short rod (state 0), a small nodule or biconcave drum (state 1), or can be an elongate rod (state 2).

33. Degree of ossification of the epibranchial gill filaments. Gill filaments on the epibranchials display variable degrees of ossification in loricariines. They can solely be ossified basally (state 0 ), up to their midlength (state 1), or for more than one half of the total length (state 2).

34. Extend of dorsolateral process of epibranchial 1 (Rapp Py-Daniel, 1997; Character 73, modified). Rapp Py-Daniel (1997) suggested that epibranchial 1 is devoid of processes in loricariines, but we found processes to be present and variably developed in the group. The dorsolateral process can be small (state 0, Fig. 13a), relatively elongate and triangular in shape (state 1; Fig. 13b), or elongate and rounded in shape (state 2; Fig. 13c).

35. Dorsolateral process of epibranchial 2 (Rapp Py-Daniel, 1997; Character 74, modified). The dorsolateral process of epibranchial 2 is highly variable in shape and position among the examined loricariids. This process can be large, well-developed and posteriorly directed (state 0; Figs. 13f,g), short and posteriorly directed (state 1; Fig. 13e), short and anteriorly directed in a mode similar to that of epibranchial 1 (state 2; Fig. 13b), or absent (state 3; Fig. 13d).

36. Dorsolateral process on epibranchial 3. Schaefer (1987) described a small dorsolateral process on epibranchial 3 of Hypostomus plecostomus, which was observed to be quite variable in shape among examined loricariids. The dorsolateral process can be elongate (state 0; Fig. 13d), or uncinate thereby forming a hook (state 1; Fig. 13b). Alternatively, the process on epibranchial 3 can be absent (state 2; Fig. 13a).

37. Ventrolateral process on epibranchial 4. Schaefer (1987) described this process as a ventrolateral expansion of the epibranchial 4, which we observed to be quite variable among examined loricariids. The process can be large and straight, covering the posterior surface of the epibranchial (state 0; Fig. 13a), large and shaped as a curved shelf (state1; Fig. 13c), or small and posteriorly directed (state 2; Fig. 13b). Alternatively, the ventrolateral process of the epibranchial 4 can be absent (state 3; Fig. 13h). 

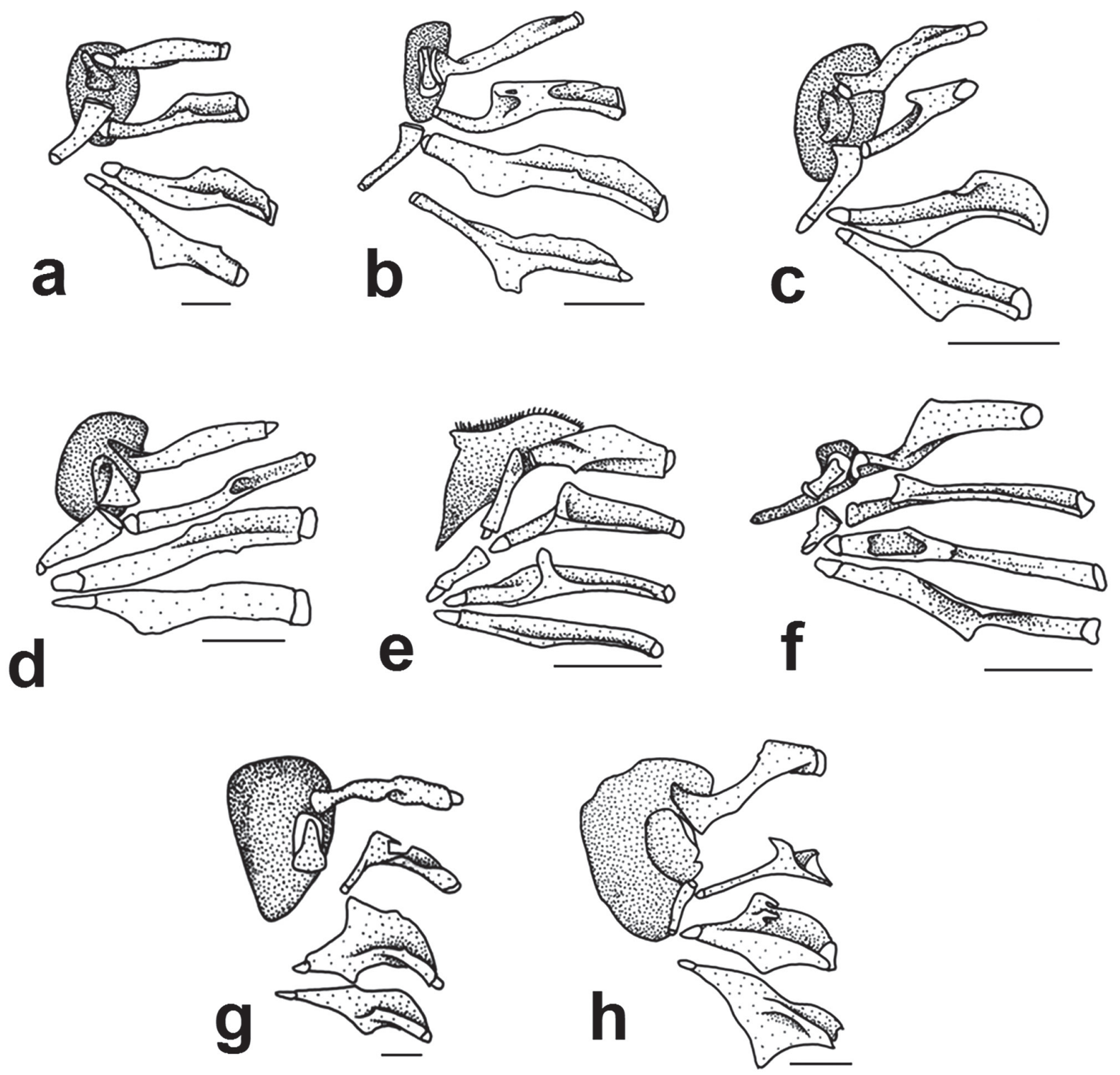

Fig. 13. Ventral view of epibranchials 1-4 of: a. Rineloricaria strigilata, MCP 42644; b. Dasyloricaria paucisquama, CPUCO 143; c. Loricariichthys anus, MCP 17235; d. Ixinandria steinbachi, MCP 41303; e. Sturisoma rostratum, MCP 36445; f. Harttia loricariformis, MCP 11707; g. Pseudohemiodon sp., MCP 36577; h. Loricaria cataphracta, MCP 41395. Anterior towards bottom. Scale bar $=2 \mathrm{~mm}$.

38. Shape of pharyngobranchial 3 (de Pinna, 1993). Pharyngobranchials 1 and 2 are absent in loricariids with pharyngobranchial 3 associated with the third epibranchial. In the examined taxa the bone is always ossified but variable in shape. It can be wide with a basal lateral process and thus somewhat boot shaped (state 0 ), wide and rod-shaped without expansions (state 1), or thin and slightly curved with a basal expansion (state 2).

39. Shape of the lower pharyngeal tooth plate (Rapp PyDaniel, 1997; character 82, modified). Ceratobranchial 5 of loricariids is expanded to form the lower pharyngeal tooth plate (Schaefer, 1987) which bears dentition of different sizes and shapes. Variation in the shape of the lower pharyngeal plate was observed among examined loricariids. The tooth plate can be rod-shaped and only slightly expanded medially (state 0; Fig. 14b), triangular (state 1; Fig. 14a), expanded ventrally with a small lateral process giving the plate an overall boot shape (state 2; Figs. 14c,f), or quadrangular or trapezoidal (state 3; Fig. 14d).

40. Thickness of the lateral portion of the lower pharyngeal tooth plate. The lateral portion of the lower pharyngeal tooth plate is as thick as the remainder of the plate in most examined species (state 0 ), or it can be expanded, very thin and translucent as in Dasyloricaria (state 1). 
41. Distribution of dentition on the lower pharyngeal tooth plate (Rapp Py-Daniel, 1997; character 85, modified). Teeth are variably distributed on the lower pharyngeal tooth plate of the examined loricariids. The teeth can be few in number and confined to a small mesial area on the plate (state 0; Fig. $14 \mathrm{e}$ ), few in number but widely spaced on the plate (state 1; Fig. 14f), more numerous and confined to the central portion of the lower plate (state 2; Fig. 14d), numerous and completely covering the plate (state 3 ; Fig. $14 \mathrm{~g}$ ).

42. Shape and size of the teeth on the lower pharyngeal tooth plate (Fichberg, 2008, character 112). A broad variation in the shape and size of the lower pharyngeal teeth was observed in the examined taxa with these differences almost certainly associated with the different feeding habits. The more general condition is short, pointed teeth (state 0; Fig. 14h). Dasyloricaria has distinctly long, pointed teeth (state 1; Fig. 14b), while some other taxa possess elongate but blunt, molariform teeth (state 2; Figs. 14 c,g).

43. Arrangement of teeth on the lower pharyngeal tooth plate (Fichberg, 2008; Character 107, modified). The arrangement of the dentition on the lower pharyngeal tooth plate varied among examined loricariids. Teeth can be randomly arranged (state 0$)$, or in one single row (state 1), two rows (state 2 ), or more than three rows (state 3 ).

44. Shape of the upper pharyngeal tooth plate (Rapp PyDaniel, 1997; Character 87, modified). Upper pharyngeal tooth plates are smaller than the lower plates and variable in shape. They can be approximately triangular with a small dorsal crest (state 0), approximately quadrangular or oval-shaped (state 1), or triangular with the anterior portion much narrower than the posterior region (state 2).

45. Shape of the teeth on the upper pharyngeal tooth plate. The upper pharyngeal tooth plate is covered with teeth. These can be all conic and pointed teeth (state 0) or, a combination of conic and molariform teeth (state 1).

46. Shape of the urohyal (Fichberg, 2008; character 77). The urohyal is an unpaired bone located ventrally to the branchial arches with two anterior projections that articulate with the hypohyal foramina. The urohyal is highly variable in shape, being an equilateral triangle (state 0 ), approximately lozenge-shaped (state 1), or having the form of an isosceles triangle with slightly convex lateral margins (state 2).
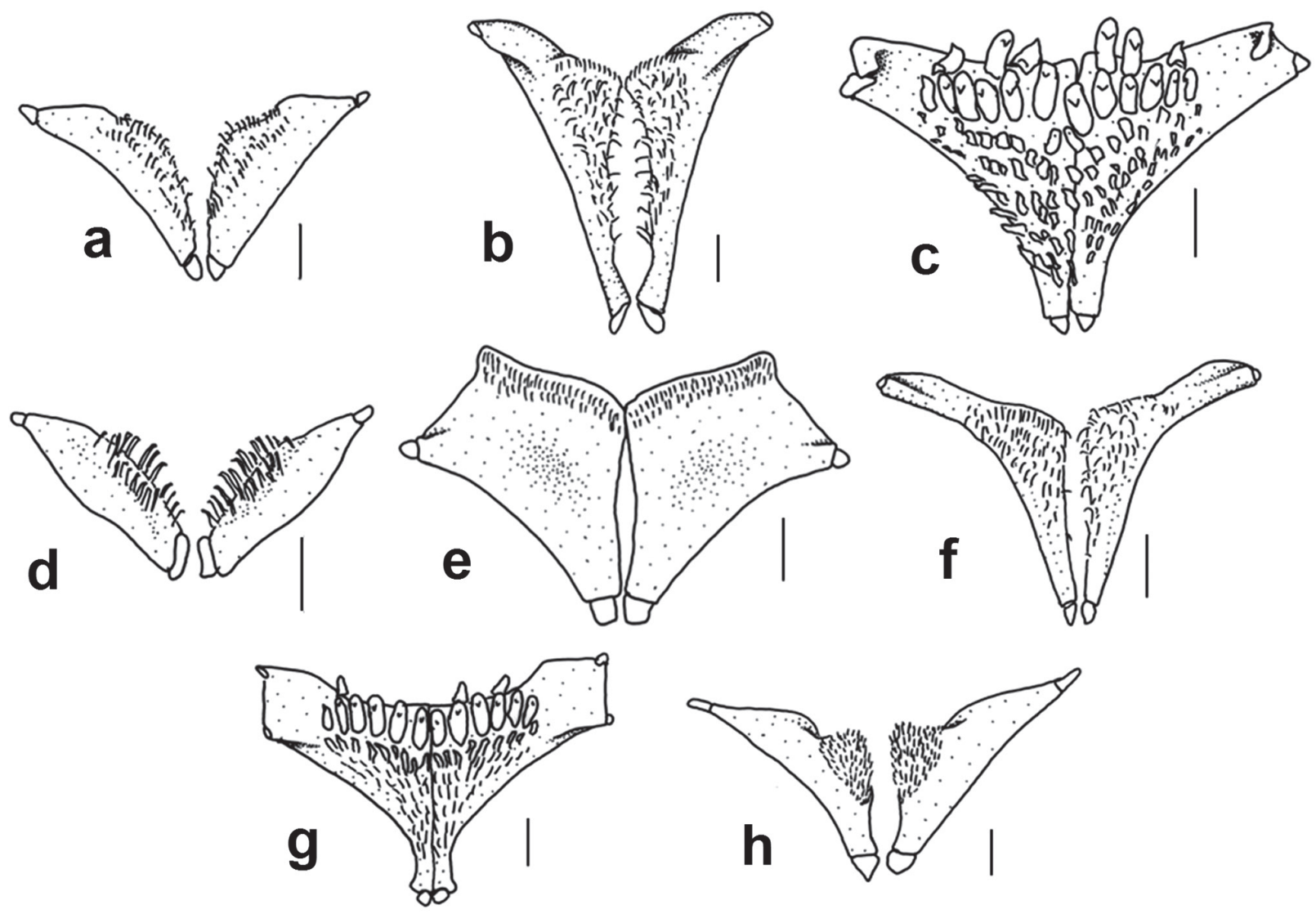

Fig. 14. Ventral view of ceratobranchial 5 of: a. Rineloricaria strigilata, MCP 42644; b. Dasyloricaria paucisquama, CPUCO 143; c. Loricaria cataphracta, MCP 41395; d. Ixinandria steinbachi, MCP 41303; e. Sturisoma rostratum, MCP 36445; f: Loricariichthys anus, MCP 17235; g. Pseudohemiodon sp., MCP 36577; h. Harttia loricariformis, MCP 11707. Anterior towards bottom. Scale bar $=1 \mathrm{~mm}$. 
Weberian apparatus and axial skeleton. The Weberian apparatus has been subject of various studies (Alexander, 1965; Chardon, 1968; Grande, 1987) in which its components and their transformations were described and interpreted. In loricariids the apparatus is formed by the first five vertebral centra and associated ribs, which are fused and possess an expansion, the transversal process of the complex centrum, which articulates with the compound pterotic and encapsulates the swim bladder (Schaefer, 1987).

47. Area of contact of the proximal portion of the connecting bone (Pereira, 2008; character 173). The connecting bone is an ossified ligament running between the rib of the sixth centrum and the dorsal-fin skeleton. The area of connection to the dorsal-fin can be to the transverse process of the second dorsal-fin pterygiophore (state 0 ) or to the nuchal plate (state 1).

48. Area of contact of the anterolateral extremity of the connecting bone to the rib of the sixth centrum (Pereira, 2008, Character 174). The pleural rib of the sixth centrum is very robust in loricariids and has an expansion at its distal tip. The anterolateral tip of the connecting bone articulates to the rib of the sixth centrum dorsal to the distal expansion (state 0 ) or alternatively to the distal expansion (state 1).

49. Number of precaudal vertebrae (Schaefer, 1987). Precaudal vertebrae are defined as those lacking a hemal spine and include the five centra fused into the Weberian apparatus. The Loricariini, except for Ixinandria, have 12 (state 1) or 11 precaudal vertebrae (state 2). Conversely, Ixinandria and the remaining examined taxa have 13 or 14 precaudal vertebrae (state 0 ).
50. Number of principal caudal-fin rays (Isbrücker, 1981). Most loricariids have 16 principal caudal-fin rays. Among the loricariines, harttiins alternatively possess 14 principal caudal-fin rays (state 0 ), and loricariins have 11-12 principal caudal-fin rays (state 1$)$.

51. Number of apophyses on the second preural centrum (Rapp Py-Daniel, 1997; Character 130). One or two apophyses, similar in shape to the hypurapophysis, are variably present on the second preural centrum. These structures can be absent (state 0; Fig. 15b), or there can be one apophysis (state 1), or two apophyses (state 2; Fig. 15a).

52. Apophyses on the third preural centrum. One apophyses, similar in shape to the apophysis on the second preural centrum is variably present on the third preural centrum. The apophysis can be absent (state 0 ), or present (state 1).

53. Extension of the lateral line (Schaefer, 1991; character 45). The length of the lateral line is variable among the examined taxa. In the basal condition, the lateral line terminates one to four plates before the supracaudal plates (state 0). In most loricariids, however, the lateral line extends to the last lateral plate before the supracaudal plates (Schaefer, 1991; state 1). Alternatively, the lateral line continues onto the supracaudal plates in most loricariines (state 2; Fig. 16b).

Pectoral girdle. 54. Form of the anterior border of cleithrum (Rapp Py-Daniel, 1997, Character 140).The anterior border of the cleithrum shows pronounced variation across loricariids. It can be straight (state 0; Fig. 17b); convex (state 1; Fig. 17c); or strongly expanded anteriorly (state 2; Fig. 17a).

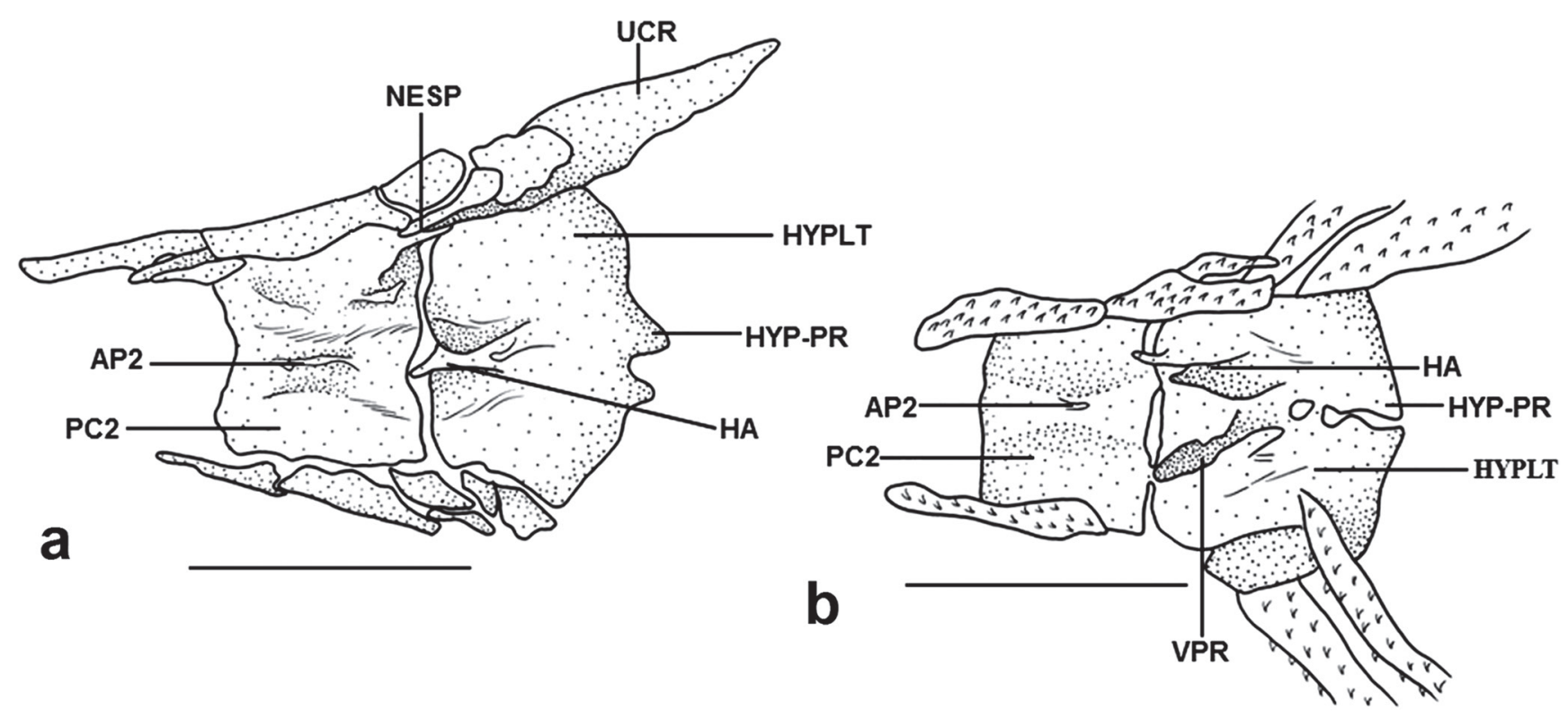

Fig. 15. Lateral view of caudal skeleton of: a. Dasyloricaria latiura, USNM 293296; b. Harttia loricariformis, MCP 11707. AP2: second central preural apophysis; NESP: neural spine; UCR: upper caudal ray; HYPLT: hypural plate; HYP-PR: hypural plate process; HA: hypurapophysis; PC2: second preural center; VPR: ventral process. Scale bar $=5 \mathrm{~mm}$. 

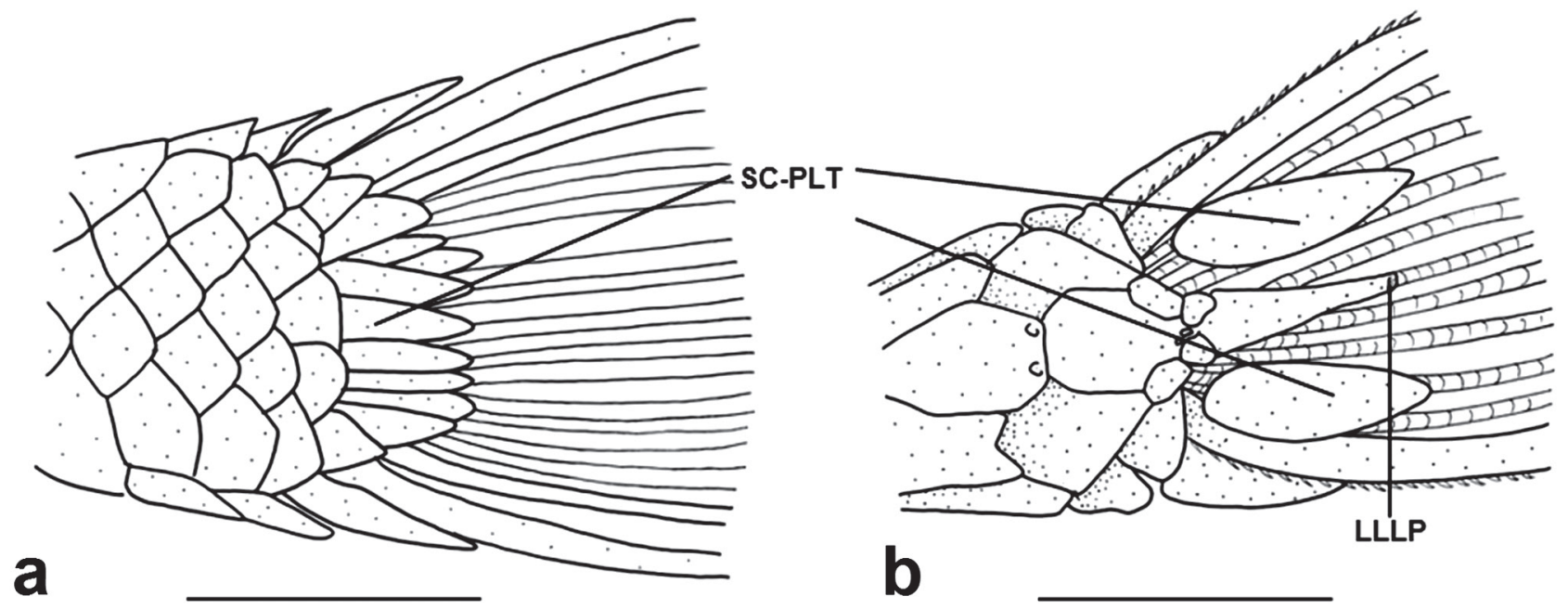

Fig. 16. Lateral view of caudal peduncle of: a. Hypostomus pyrineusi, MCP 35814; b. Dasyloricaria paucisquama, MPUJ 6019. SC-PLT: supracaudal plates; LLLP: last lateral line pore. Scale bar $=5 \mathrm{~mm}$.
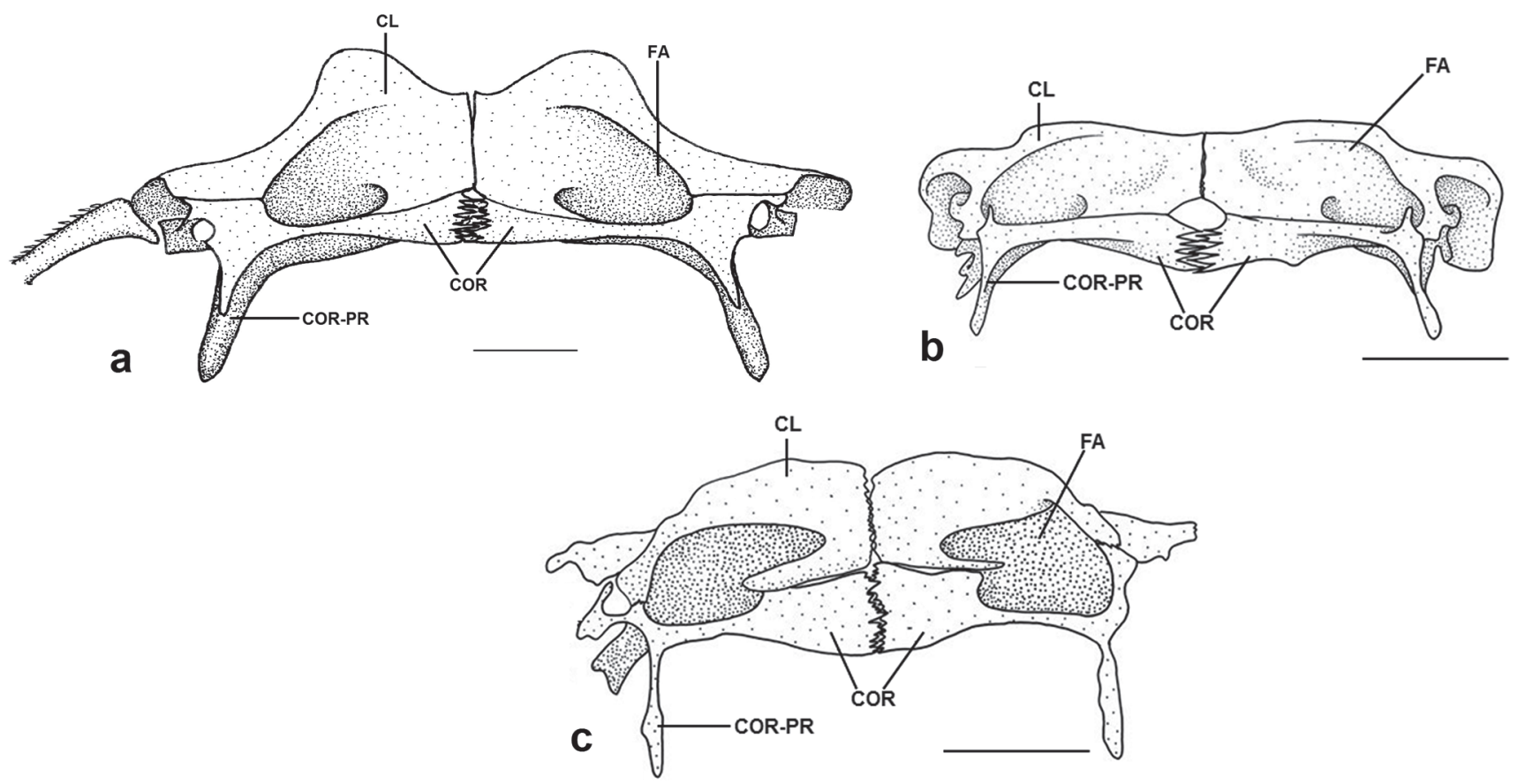

Fig. 17. Ventral view of pectoral girdle of: a. Dasyloricaria paucisquama, CP-UCO 143; b. Ixinandria steinbachi, MCP 41303; c. Spatuloricaria tuira, MZUSP 94853. CL: cleitrhum; FA: fossa abductor; COR: coracoids; COR-PR: coracoids process. Scale bar $=5 \mathrm{~mm}$.

55. Form of the posterior process of the coracoid (Rapp PyDaniel, 1997; character 145). The posterior process of the coracoid of loricariids can be strong, robust and with a wide posterior tip (state 0). Among the loricariines, the posterior process of the coracoid is instead long, thin and pointed (state 1; Figs. 17 b,c), or short, thin and pointed (state 2; Fig. 17 a).

56. Opening of the arrector fossa (Schaefer, 1991; Character 41). The arrector fossa in the ventral surface of the pectoral girdle of loricariids (Fig. 17) can be wide and deep (state 0), or in the form of a shallow depression (state 1).
Pelvic girdle. 57. Length of the cartilage at the basipterygial symphysis. The contralateral basipterygia are sutured anteriorly and posteriorly at the midline, and synchondrally united centrally. The cartilaginous portion can be short when its length is less than one-half the length of the total articulation (state 0; Fig. 18 c), or long and comprising more than one-half of the length of the articulation between the basipterygia (state 1; Figs. 18 a,b).

58. Medial anterior process of basipterygium (Schaefer, 1990; character 49). The basipterygium of catfishes has a pair 
of anterior processes. Among the examined loricariids the medial anterior processes of the basipterygia are convergent but not in contact (state 0), or they can contact each other medially and be followed by a large fenestra (state 1), or they can contact each other and are not followed by a fenestra (state 2).

59. Relationships of lateral anterior processes of basipterygium (Schaefer, 1990; character 49). The lateral anterior processes of the basipterygia can be separated and never in contact (state 0; Figs. 18a,c). Conversely, they can be extensively fused medially and becoming indistinguishable (state 1).

60. Shape of the lateropterygium (Schaefer, 1987, character 30). The lateropterygium is a small anterodorsally oriented shaft of bone articulated to the lateral region of the pelvic basipterygium in astroblepids and loricariids (Shelden, 1937; Schaefer, 1987). Among the examined taxa, the lateropterygium can be long and club-shaped with its distal tip expanded (state 0 ), very reduced in form of a bony nodule (state 1), short with an expanded somewhat triangular or mushroom-like shaped proximal portion (state 2), or long, thin and spine-like without a distal expansion (state 3). The lateropterygium is absent in Hemiodontichthys (state 4).

External morphology. 61. Ornamentation of the lower lip margin (Rapp Py-Daniel, 1997, Character, 177; modified). The ornamentation of the lower lip margin is highly variable among loricariids. In some groups the lower lip margin is smooth and unornamented (state 0). Alternatively, it can have small papillae, similar to those on the lower lip (state 1), short filaments forming a fringed border (state 2), or long filaments, which may reach to the gill opening (state 3).

62. Shape of the papillae covering the lower lip (Rapp PyDaniel, 1997, Character, 181). Harttia and most Loricariini have small, roundish papillae on the lower lip (state 0), while Loricaria and Pseudohemiodon have the elongate filamentlike papillae (state 1). Pseudoloricaria lacks papillae and the lower lip is smooth (state 2).
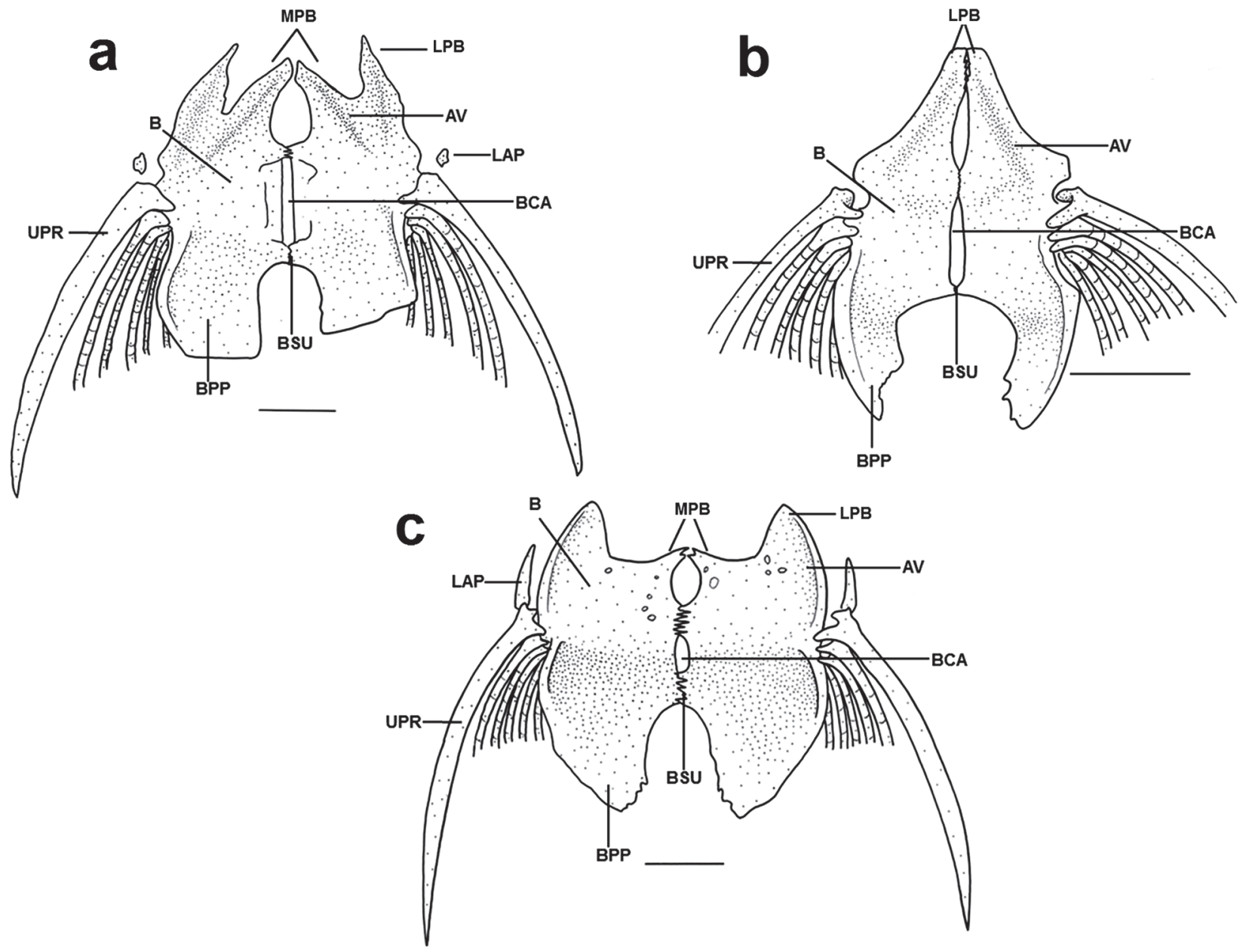

Fig. 18. Ventral view of pelvic girdle of: a. Dasyloricaria paucisquama, CP-UCO 143; b. Loricaria cataphracta, MCP 41395; c. Harttia loricariformis, MCP 11707. MPB: medial process of basipterygium; LPB: lateral process of basipterigium; AV: arrector ventralis; LAP: lateropterygium; BCA: basipterygia cartilage; BSU: basipterygia suture; BPP: basipterygia posterior process; UPR: unbranched pectoral ray; B: basipterygia. Scale bar $=5 \mathrm{~mm}$. 
63. Elaboration of the oral cavity immediately behind the premaxilla (Rapp Py-Daniel, 1997, Character 182; modified). The anterior roof of the oral cavity, immediately behind the premaxillae is elaborated into papillae in various loricariids. These papillae can be rounded and smaller than those on the lower lip (state 0 ), ovate and large, similar to those on the lower lip, as in Dasyloricaria (state 1), irregularly shaped and rather large, as in Loricariichthys (state 2), or filamentous, as in Loricaria and Pseudohemiodon (state 3). Papillae behind the premaxilla can also be absent (state 4).

64. Shape of the papillae along upper lip margin (Fichberg, 2008, character 165; modified). A great amount of variation occurs in the shape of the papillae ornamenting the upper lip margin. Among the examined taxa some have no papillae along the upper lip margin (state 0 ), some others have rounded papillae similar to those on the lower lip (state 1), and still others have filaments, either branched or unbranched along the upper lip margin (state 2).

65. Elaboration of the maxillary barbel (Fichberg, 2008, character 165; modified). Different elaborations of the maxillary barbel occur across loricariids. The maxillary barbel can be simple and unelaborated (state 0 ), or it can have unbranched or branched filaments (state 1).

66. Thick fleshy filaments anterior to the premaxillary teeth. Dasyloricaria has four to six thick, fleshy filaments on the outer margin of the upper lip anterior to the premaxillary teeth (state 1; Fig. 19). These filaments are absent in the remaining examined taxa (state 0 ).

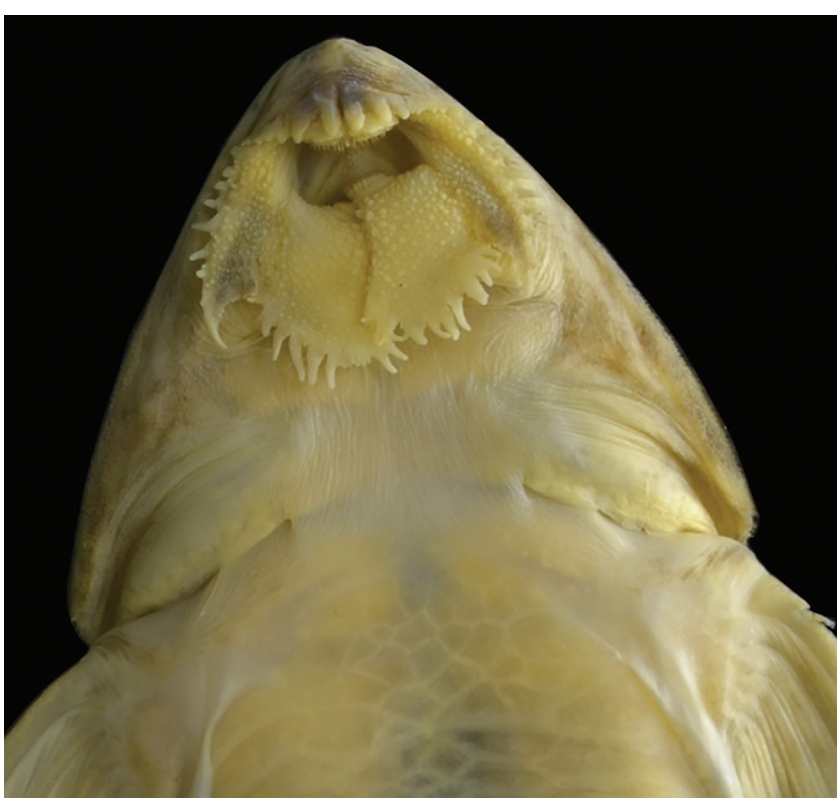

Fig. 19. Ventral view of snout in Dasyloricaria filamentosa, CP-UCO 350, $192.9 \mathrm{~mm}$ SL showing thick fleshy filaments on upper lip.
67. Number of premaxillary teeth in adults. Isbrücker (1981) was the first author to suggest that the number of premaxillary teeth could be used to distinguish between various supra-generic taxa within the Loricariinae; a suggestion confirmed in the present study. Species belonging to Harttiini typically have more than 20 teeth on each premaxillae (state 0), Ixinandria has more than 10 but fewer than 20 premaxillary teeth o 20 (state 1). Conversely, Dasyloricaria as well as most of the Loricariini typically possess between three and nine teeth (state 2) in some instances lack premaxillary teeth (state 3 ).

68. Size of the teeth on the premaxilla relative to those on the dentary (Fichberg, 2008, Character 170). Dentary teeth among examined taxa do not vary much in size compared to those on the premaxilla. Premaxillary teeth can be similar in size to those of the dentary (state 0), smaller than the dentary teeth (state 1), conspicuously larger than the dentary teeth (state 2). Hemiodontichthys has no premaxillary teeth and this character is thus innaplicable.

69. Parieto-supraoccipital crests (Rapp Py-Daniel, 1997, Character 187).

Most examined taxa lack crests on the parietosupraoccipital (state 0). Conversely, Rineloricaria, Hemiodontichthys, Dasyloricaria, and Spatuloricaria possess two conspicuous, slightly divergent crests on the parieto-supraoccipital (state 1).

70. Odontodes covering the lateral margin of the head in adult males (Pereira, 2008, Character 278; modified). Hypertrophied odontodes on the lateral margin of the head are a sexually dimorphic feature present in several groups of loricariids. Among the examined taxa, odontodes covering the margins of the head in adult males can be similar to those covering the remainder of the head surface (state 0 ), or conspicuously hypertrophied relative to those on the remainder of the head (state 1).

71. Coverage of the abdomen by the central abdominal plates. A great amount of variation in the degree of coverage of the abdomen by central abdominal plates occurs among loricariids with some of the differences reflecting ontogenetic differences (Figs. 20a-c). In some of the examined taxa the abdomen is naked, having any central abdominal plates (state 0 ). Alternatively, the central portion of the abdomen can be partially or totally covered by plates in adults (state 1).

72. Size of the posterior abdominal plates. Posterior abdominal plates are those located more posteriorly on the abdomen, usually between the pelvic fins. These plates can be similar in size to those more anteriorly placed plates on the central portion of the abdomen (state 0 ), or can be larger (state 1), or smaller (state 2). This character is inapplicable to taxa without central abdominal plates and those taxa were coded accordingly. 

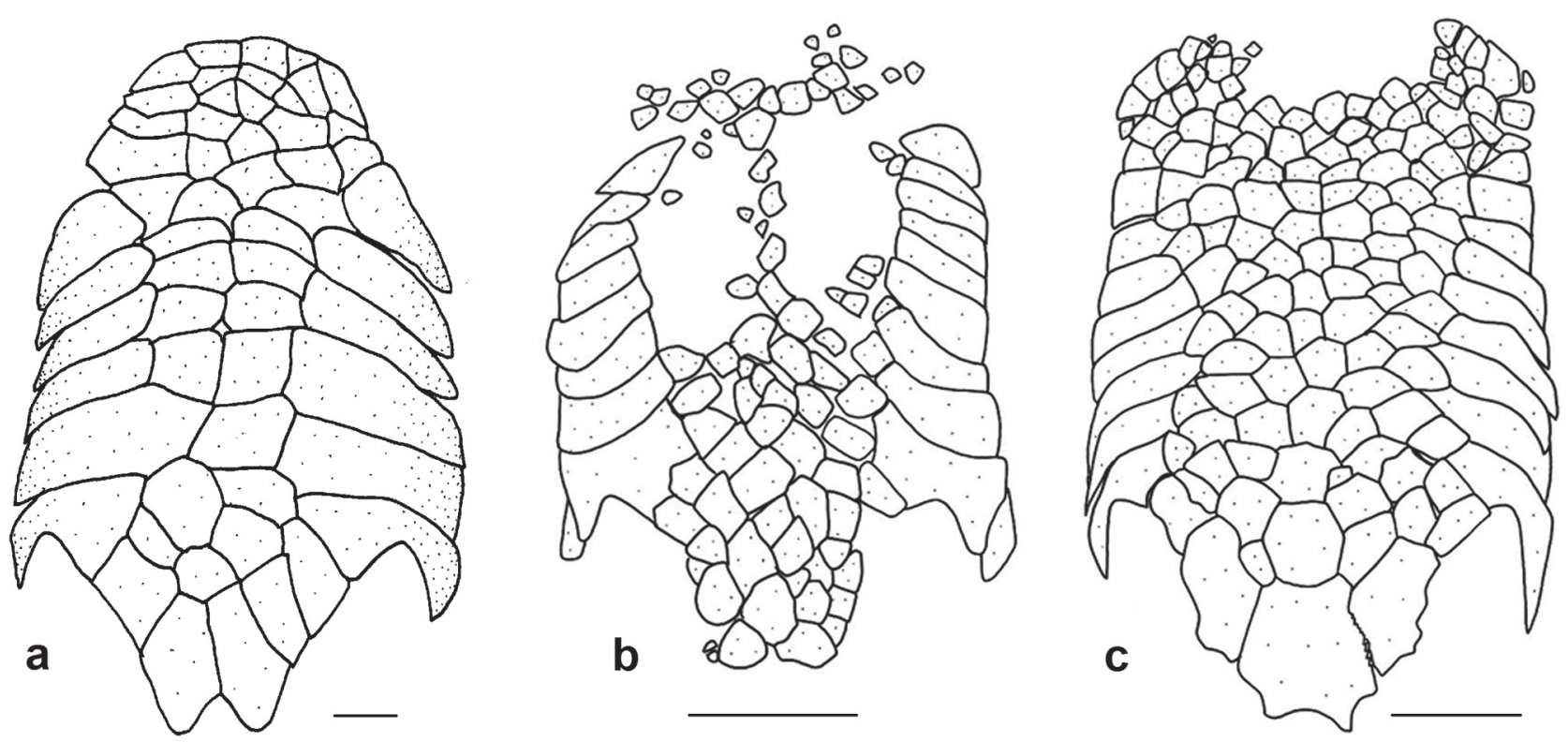

Fig. 20. Ventral view of abdominal plates pattern of: a. Dasyloricaria paucisquama, MPUJ 6019; b. Loricaria cataphracta, MCP 41395; c. Rineloricaria strigilata, MCP 42644. Scale bar $=5 \mathrm{~mm}$.

73. Transverse dark bar on head extending over the eyes. All species of Dasyloricaria possess a transverse bar of dark pigmentation on head that extends over the eyes and sometimes anteriorly onto the snout (state 1; Figs. 3, 5, 7). This dark bar is absent in the remaining examined taxa (state 0 ). Some species of Paraloricaria, not included in the present analysis, possess a similar dark bar, located between the snout tip and the anterior border of the orbits.

74. Position of the pelvic-fin insertion (Fichberg, 2008, character 179). The point of the pelvic-fin origin varies among examined taxa being either approximately along the vertical through the dorsal-fin origin (state 0 ) or anterior to the vertical through the dorsal-fin origin (state 1).

Phylogenetic analysis. The phylogenetic analysis of the unweighted and unordered data matrix resulted in a single most parsimonious tree (Fig. 21) with a length of 253 steps, consistency index of 0.54 and retention index of 0.65 . Dasyloricaria was recovered as monophyletic (Fig. 21; see generic diagnosis) and containing three valid species. Dasyloricaria filamentosa was found to be sister to $D$. latiura on the basis of two non-unique synapomorphies: (1) the parasphenoid broad at its articulation with the basioccipital (character 5.1); and (2) the possession of a bar-shaped dorsolateral process of the lateral ethmoid (character 6.0).

Isbrücker (1979, 1980) suggested the inclusion of Dasyloricaria in the subtribe Rineloricariina, along with Rineloricaria, Spatuloricaria and Ixinandria. This suggestion was based on external morphology (including characters of sexual dimorphism) without a phylogenetic analysis. We tested and only partially corroborated this hypothesis. Spatuloricaria was recovered as sister to Dasyloricaria (Fig. 21) with this clade diagnosed by two exclusive synapomorphies: (1) the presence of a relatively elongate and triangular dorsolateral process of epibranchial 1 (character 34.1); and (2) the papillae in the oral cavity immediately behind the premaxilla being large, circular and similar to those on the lower lip (polymorphic for Spatuloricaria; character 63.1) plus the following nonunique synapomorphies: (3) the dorsolateral process on epibranchial 3 uncinated (character 36.1); and (4) the presence of apophyses on the third preural centrum (character 52.1).

In addition, Rineloricaria was recovered as sister to the Dasyloricaria+Spatuloricaria clade (Fig. 21) with the relationship among these three genera supported by one unique synapomorphie: (1) the epiphyseal pore of the supraorbital sensory canal forming a groove (character 16.2), and by three non-unique synapormorphies: (2) the ornamentation of the predorsal plates formed by low crests (character 10.1); (3) the lower pharyngeal tooth plate completely covered by numerous teeth (character 41.3 ); and (4) the parieto-supraoccipital with two conspicuous, slightly divergent crests (character 69.1)

Ixinandria, on the other hand, was recovered as the sister group to all the Loricariini (Fig. 21) and not being closely related to the genera of to the Rineloricariina sensu Isbrücker (1979). That subtribe is, thus, partially corroborated (Rineloricaria, Spatuloricaria, and Dasyloricaria, with Ixinandria excluded); however, we defer from proposing major taxonomic rearrangements regarding subtribal composition or proposing new groups in the absence of the extensive sampling of members of these genera necessary to achieve a well-supported hypothesis of their interrelationships. 


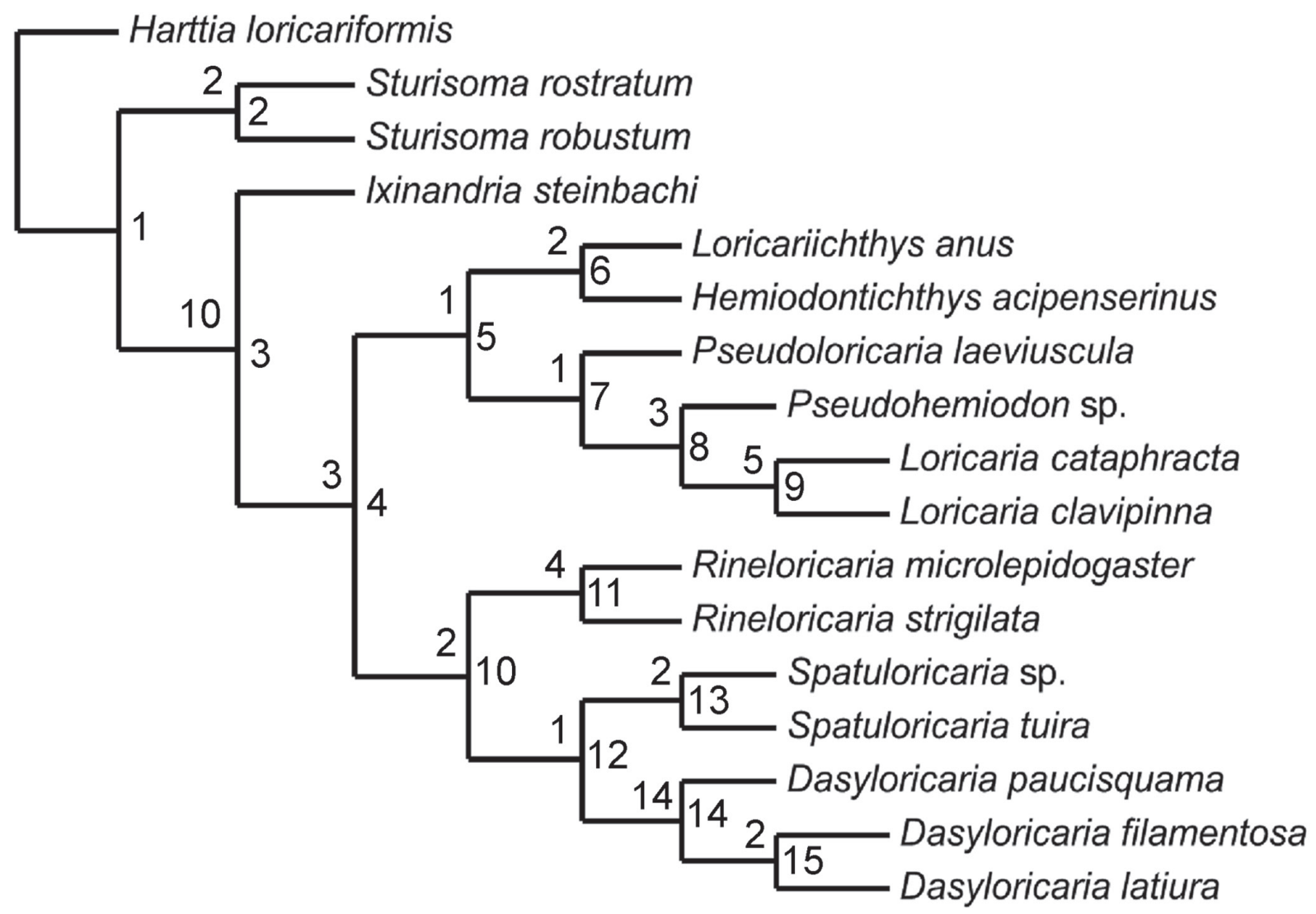

Fig. 21. Maximum parsimonious tree showing intra and interspecific relationships of Dasyloricaria and part of the Loricariini. Length: 253 steps, consistency index (CI): 0.54, and retention index (RI): 0.65. Node numbers inside nodes. Bremer support values above branches. See character-state transformations in Appendix II.

\section{Discussion}

Dasyloricaria was described by Isbrücker \& Nijssen (in Isbrücker, 1979) to include a total of five species: D.capetensis, D. filamentosa (type species), D. latiura, D. seminuda and D. tuyrensis. Here these species were analyzed using both taxonomic and phylogenetic approaches with only two of the species considered valid: D. filamentosa and D. latiura. In addition, D. paucisquama is herein described as new from the upper and middle río Magdalena. Disagreements regarding the validity of Dasyloricaria species by some authors (i.e. Meek \& Hildebrand, 1916; Eigenmann, 1922; Dahl, 1971; Galvis et al., 1997) were resolved.

Dasyloricaria seminuda is herein regarded as a junior synonym of $D$. filamentosa, corroborating the observation of Eigenmann \& Vance (in Eigenmann, 1912) who in their original description of Loricaria filamentosa seminuda commented that despite differences in the space between the central and lateral abdominal plates (the only character differentiating those species), "in [all] other respects this species is like the typical specimens of filamentosa" (Eigenmann, 1912: 13; Eigenmann, 1922: 91). Dahl (1971) similarly has considered these species as synonyms, an action not followed by several subsequent authors (e.g. Isbrücker, 1980; Ferraris, 2003, 2007; Maldonado-Ocampo, 2005;
Covain \& Fisch-Muller, 2007). Additionally, MaldonadoOcampo et al. (2005) reproduced part of the description offered by Eigenmann \& Vance of D. filamentosa (see Remarks on $D$. filamentosa), mistakenly presenting that as a description of $D$. seminuda. We agree with reports by Maldonado-Ocampo et al. (2005) and Ferraris (2007) of the presence of $D$. filamentosa in the Magdalena and Catatumbo basins, but noted that this species is also found in the río Sinú and lago Maracaibo basins (Fig. 2). The second subspecies related to $D$. filamentosa described by Eigenmann \& Vance (in Eigenmann, 1912) is Loricaria filamentosa latiura. Again, only one feature was used by the authors to differentiate these two taxa: the width of body and tail, specifically at the base of the last anal-fin ray. The usefulness of that measurement to differentiate $D$. latiura from $D$. filamentosa was tested in this study, and it was demonstrated that this character shows extensive overlap (see Tables 1,3) and fails to differentiate the species. Several osteological and external diagnostic characters were found to diagnose these species such as the number of dark transverse bars on the dorsum, the configuration of anterior and central abdominal plates, the coloration of the anal fin, the dark bar extending over the eyes, and the presence of a conspicuous plate next to the pectoral-fin origin. Furthermore, the populations belonging to each of the species are completely allopatric. 
Previous papers dealing with the phylogenetic relationships of Dasyloricaria included either only one species or two nominal species that were regarded as synonyms in the present study, precluding a comparison with our intrageneric phylogeny. Both Covain et al. (2008) and Rodriguez et al. (2011) included Dasyloricaria tuyrensis in their molecular analyses of the Loricariinae, recovering the genus close to the base of the Loricariini, sister-group to a big clade including most Loricariini except Metaloricaria. In addition, Covain et al. (2016) included Dasyloricaria latiura and D. tuyrensis (herein considered to be synonyms) in their recent reassessment of the Loricariinae phylogeny. Covain et al. (2016) recovered Dasyloricaria as sister to Fonchiiloricaria, and that clade nested near the base of their Loricariina.

The molecular analyses mentioned above never found evidence to corroborate, either totally or in part, the Rineloricariina of Isbrücker (1980), contrary to what we found in morphological grounds that leaves Ixinandria close to the base of the Loricariini, but recovers Dasyloricaria, Spatuloricaria, and Rineloricaria as closely related, thus partially corroborating the subtribe Rineloricariina.

As noted by Covain \& Fisch-Muller (2007), Dasyloricaria remains as the only entirely trans-Andean genus in the Loricariinae, contrary to Spatuloricaria, its sister group, which has representatives on both the Pacific and Atlantic slopes (Ferraris, 2007; Eschmeyer \& Fong, 2015). The unique distribution pattern of Dasyloricaria can be attributed to either a relict isolated population, which subsequently diversified after the uplifting of the Merida Andes and Perijá Mountains which separated the Magdalena from the lago Maracaibo basin, and the uplifting of the central and western versants which isolated the Cauca basin (a tributary to the Magdalena, although separated from it by the central cordillera; Schaefer, 2011) from the western basins such as the Atrato, San Juan, Patía, Baudó (Colombia) and Tuyra (Panama) basins; or to ecological restrictions related to niche requirements, resources, or specific habitat characteristics.

Comparative material examined. Dasyloricaria filamentosa: Colombia: FMNH 55116, 1, 175.3 mm SL (holotype of Loricaria filamentosa seminuda), Girardot. FMNH 55113, 2, 160.0-215.6 mm SL, Soplaviento, lower río Magdalena. FMNH 55114, 1, $287.6 \mathrm{~mm}$ SL, Calamar, lower río Magdalena. CAR 523, 1, 208.0 mm SL, Cesar Department, río Cesar, lower río Magdalena. CAS 13187, 3 of 6, 199.0-266.0 mm SL, Bolivar Department, Soplaviento, lower río Magdalena. CIUA 198, 7, 178.3-220.5 mm SL, Ciénaga de Ayapel, lower río Magdalena. CIUA 368, 4, 76.3-150.1 mm SL, confluence of río Tucuy and río Maracas, río Calenturitas, lower Magdalena basin. CIUA 520, 1, 240.9 mm SL, Ciénaga, lower Magdalena basin. CIUA 872, 1, $163.0 \mathrm{~mm}$ SL, CIUA 890, 1, 157.3 mm SL, CIUA 1012,1, $189.8 \mathrm{~mm}$ SL, and CIUA 1034, 1, $128.7 \mathrm{~mm}$ SL, río La Miel, middle Magdalena basin. CIUA 1013, 1, $210.1 \mathrm{~mm}$ SL, río La Miel at La Palmera, Magdalena basin. CP-UCO 161, 1, $167.6 \mathrm{~mm}$ SL, Antioquia, río Samaná, tributary to río La Miel at
Butantan, $5^{\circ} 41^{\prime} \mathrm{N} 74^{\circ} 46^{\prime} \mathrm{W}$. CP-UCO 350, 1, 192.9 mm SL, Caldas, Norcasia, río La Miel at La Cachaza, middle Magdalena basin, 5³9’N 7446’W. CP-UCO 1215, 1, 277.2 mm SL, Antioquia, río Nechí at confluence with río Cauca, lower Cauca basin. CP-UCO 1356, 2, 195.3-196.3 mm SL, Cesar, El Paso, río Cesar, río Magdalena basin. CP-UCO 1359, 6, 1 c\&s, 184.3-214.9 mm SL, Cesar, El Paso, río Cesar, río Magdalena basin. IAvH-P 3086, 1 of 4, $238.6 \mathrm{~mm}$ SL, Norte de Santander, San Calixto, río Zulia, río Catatumbo basin. IAvH-P 3845, 5, 125.4-170.1 mm SL, Boyacá, Puerto Boyacá, quebrada Palagua, middle Magdalena basin. IAvH-P 3846, 7, 168.1-194.8 mm SL, Boyacá, Puerto Boyacá, Velasquez creek, middle Magdalena basin. IAvH-P 12938, 7, 162.2-185.3 mm SL, Boyacá, Puerto Boyacá, Palagua and Velasquez creeks, middle Magdalena basin. MPUJ 1843, 2 of 3, 164.4-187.0 mm SL, caño Tucuy, río Cesar, lower Magdalena basin. SU 49470, 3, 126.3-134.8 mm SL, Sucre, Sincelejo, Pozo del Chorro, río Sinú basin. UIS-T 1515, 1 of 2, $77.7 \mathrm{~mm}$ SL, Santander, Betulia, quebrada La Putana, río Sogamoso basin, middle Magdalena basin. UIS-T 1847, 1, 188.8 mm SL, Santander, Puerto Wilches, quebrada La Putana, río Sogamoso, middle Magdalena basin. UIS-T 1849, 1, $167.5 \mathrm{~mm}$ SL, Santander, San Vicente de Chucurí, río Chucurí, middle Magdalena basin. UIS-T 1850, 1, $159.5 \mathrm{~mm}$ SL, Santander, Puerto Wilches, río Sogamoso below bridge, middle Magdalena basin. UIS-T 1851, 1, $208.1 \mathrm{~mm}$ SL, Santander, San Vicente de Chucurí, Naranjito path, La Paz bridge, río Sogamoso, middle Magdalena basin. USNM 175296, 5, 63.4123.1 mm SL, Córdoba, Betanci, Sinú, Córdoba, río Sinú basin. Venezuela: USNM 121085, 1, $245.2 \mathrm{~mm}$ SL, Maracaibo Lake basin, creek 1/2 mile West of the city of Sinamaica, Zulia state. USNM 121086, 1, $278.1 \mathrm{~mm}$ SL, lago Maracaibo basin, río Agua Caliente, 2 to $3 \mathrm{~km}$ above lago Maracaibo. USNM 121088, 2 of 8, 56.5 and $67.4 \mathrm{~mm}$ SL, lago Maracaibo basin, río Negro below mouth of río Yasa. USNM 121089, 1, $89.3 \mathrm{~mm}$ SL, lago Maracaibo basin, río Palmar at bridge $70 \mathrm{~km} \mathrm{SW}$ of Maracaibo. USNM 121090, 1, $178.6 \mathrm{~mm}$ SL, lago Maracaibo basin, Tule Lake approximately $75 \mathrm{~km} \mathrm{~W}$ of Maracaibo, $5 \mathrm{~km}$ from río Socuy. Dasyloricaria latiura: Colombia: FMNH 124472, 1, $220.0 \mathrm{~mm}$ SL (designated herein as lectotype) Boca de Certegui, río Atrato basin. FMNH 55115, 6, 189.8-219.0 mm SL (paralectotypes) collected with lectotype. CAS 13187, 3 of 6, 193.9-237.6 mm SL, Boca de Certegui, río Atrato basin. CIUA 226, 1, $260.0 \mathrm{~mm}$ SL, río Atrato basin, last cienaga of Tumaradó. IAvH-P 6770, 3, 129.2175.4 mm SL, Chocó, Lloró, río Atrato basin, río Capá. IAvH-P 6772, 1, 171.3 mm SL, Chocó, Quibdó, río Atrato basin, río Cabi at La Playita. IAvH-P 6773, 1, 212.0 mm SL, Chocó, Yuto, río Atrato basin, creek at río Atrato. IAvH-P 6774, 3, 215.1-246.8 mm SL, Chocó, Yuto, río Atrato basin, río Yuto. IAvH-P 6775, 2, 200.9245.9 mm SL, Chocó, río Atrato basin, río Yuto. IAvH-P 6776, 1, $203.3 \mathrm{~mm}$ SL, Chocó, Yuto, río Atrato basin, río Yuto. IAvH-P 6777, 2, 179.0-222.0 mm SL, Chocó, río Atrato basin, río Yuto. IAvH-P 6778, 1, 216.3 mm SL, Chocó, Yuto, río Atrato. IAvH-P 6779, 2, 166.1-203.9 mm SL, Chocó, Yuto, río Atrato basin, río Yuto. IAvH-P 7265, 2, 124.3-126.8 mm SL, Antioquia, Turbo, río Atrato basin, last Cienaga Tumarado, El Cuarenta path. IAvH-P 7297, 1, $209.1 \mathrm{~mm}$ SL, Chocó, Unguia, río Atrato in Tumarado. IAvH-P 7298, 1, 162.6 mm SL, Chocó, Unguia, río Atrato in 
Tumarado. IAvH-P 7316, 3, 243.9-287.6 mm SL, Chocó, Unguia, río Atrato in Tumarado. IAvH-P 7317, 1, $263.4 \mathrm{~mm}$ SL, Chocó, Unguia, río Atrato in Tumarado. IAvH-P 7318, 2, 215.5-216.6 mm SL, Chocó, Unguia, río Atrato in Tumarado. IAvH-P 7319, 1, 1 c\&s, 205.0-213.2 mm SL, Chocó, Unguia, río Atrato basin, Unguia swamp and its creeks. NRM 15156, 2, 288.6-291.4 mm SL, Antioquia, río Atrato basin, río Buchadó at shore of small village. Panama: FMNH 7582, 1, 141.4 mm SL (holotype of Loricaria capetensis), Darién, río Tuyra basin, río Capeti. FMNH 7583, 1, $285.2 \mathrm{~mm}$ SL (holotype of Loricaria tuyrensis), Darién, río Tuyra basin, Boca de Cupe. FMNH 29310, 1, $246.1 \mathrm{~mm}$ SL (paratype of Loricaria tuyrensis), Darién, río Tuyra basin, Boca de Cupe. FMNH 29311, 1, 243.4 mm SL (paratype of Loricaria tuyrensis), Darién, río Tuyra basin, Boca de Cupe. FMNH 29312, 1, 250.3 mm SL (paratype of Loricaria tuyrensis), Darién, río Tuyra basin, Boca de Cupe. FMNH 29313, 1, 248.9 mm SL (paratype of Loricaria tuyrensis), Darién, río Tuyra basin, Boca de Cupe. FMNH 29314, 1, $265.1 \mathrm{~mm}$ SL (paratype of Loricaria tuyrensis), Darién, río Tuyra basin, Boca de Cupe. FMNH 29315, 1, 306.7 mm SL (catalogued as "paratype?" of Loricaria tuyrensis), Panama. FMNH 29316, 1, 236.2 mm SL (catalogued as "paratype?" of Loricaria tuyrensis), Panama. FMNH 29317, 1, 285.0 mm SL (paratype of Loricaria tuyrensis), Darién, río Tuyra basin, Boca de Cupe. FMNH 29318, 1, 225.2 mm SL (paratype of Loricaria tuyrense), Darién, río Tuyra basin, Boca de Cupe. USNM 280393 , 1, $139.1 \mathrm{~mm}$ SL, Darién, río Tuyra $1 / 2 \mathrm{~km}$ above Boca de Cupe. USNM 293168, 1, 236.3 mm SL, Darién, Tuyra between Calle Larga and Pinogana above El Real. USNM 293296, 1 c\&s, Panama, Darien, Province of Darien, río Tuyra $1 / 2 \mathrm{~km}$ above Boca de Cupe. USNM 293575, 1, 77.8 mm SL, Darién, río Tuyra basin, río Pucuro above confluence with río Tuyra. Harttia loricariformis: Brazil: MCP 11707, 1, 1 c\&s, Rio de Janeiro, rio Paraíba do Sul on road between Piraí and Vassouras. MCP 31309, 7, Espírito Santo, Itaguacú, rio Santa Joana. MCP 31321, 4, Espírito Santo, Itarana, rio Limoeiro at Praça Oito, rio Doce basin. Hemiodontichthys acipenserinus: Brazil: MCP 21975, 6, 1 c\&s, Maranhão, rio Pindaré W of Santa Inês. MCP 29792, 5, Amazonas, Alvarães, Paraná Maiana $2.5 \mathrm{~km}$ from town Boca do Mamirauá. Hypostomus pyrineusi: Brazil: MCP 35814, 5, 1 c\&s, Rondônia, Ouro Preto, small creek running NE on right margin of rio Jarú, at road BR-364 between Ouro Preto D'Oeste and Jaru, rio Madeira basin. MCP 35822, 4, Rondônia, Presidente Médici, small creek tributary to the right margin of rio Machado near km 280 of road BR-364, rio Madeira basin. Ixinandria steinbachi: Argentina: MCNI 099, 1, 1 c\&s, río Juramento, río Paraná basin. MCP 41303, 32, 1 c\&s, río Arenales, tributary to río Juramento, río Paraná basin. MCP 41918, 7, Salta, río La Caldera, tributary to río Bermejo, río Paraná basin. Loricaria cataphracta: Brazil: MCP 41395, 2, 1 c\&s, Goiás, Piranhas, rio Piranhas near to mouth of rio São Domingos, rio Tocantins basin. MCP 41864, 1, Goiás, Piranhas, Volta Grande creek, tributary to left margin of Piranhas Electric Powerplant reservoir, rio Tocantins basin. MCP 44713, 2, Goiás, Itapirapuã, rio Vermelho, rio Tocantins basin. Loricaria clavipinna: Peru: MCP 45735, 5, 1 c\&s, Ucayali, río Purus basin, quebrada Pinto Yaco near to mouth of río Purus. Loricariichthys anus: Brazil: MCP 11271, 10, Rio Grande do Sul, Erval, rio Uruguay basin, rio
Jaguarão at Passo do Centurião. MCP 17235, 1 c\&s, Rio Grande do Sul, Porto Alegre, rio Jacuí basin, rio Jacuí delta at Saco da Alemoa. Pseudohemiodon sp.: Brazil: MCP 36575, 1, Acre, Xapuri, rio Purus basin, rio Acre at Xapuri. MCP 36577, 1 c\&s, Rondônia, Presidente Médici, rio Madeira basin, rio Leitão at road BR-364 ca. 5 km N of Presidente Médici. MCP 36578, 2, Acre, Xapuri, rio Purus basin, rio Acre at Xapuri. Pseudoloricaria laeviuscula: Brazil: MCP 44362, 10, 1 c\&s, Pará, Santerém, rio Tapajós basin, rio Tapajós between Santarém and Itaituba. Rineloricaria microlepidogaster: Brazil: MCP 19442, 1, Rio Grande do Sul, Caraá, rio Jacuí basin, arroio Carvalho at Caraá. MCP 21254, 10, Rio Grande do Sul, Agudo, rio Jacuí basin, arroio Linha das Flores ca. $10 \mathrm{~km}$ NNW of Agudo on road to Dona Francisca hydrolectric powerplant. MCP 37690, 1 c\&s, Rio Grande do Sul, Bento Gonçalves, rio Jacuí basin, Monte Claro reservoir. MCP 37691, 1 c\&s, Rio Grande do Sul, Veranópolis, rio Jacuí basin, Monte Claro reservoir. Rineloricaria strigilata: Brazil: MCP 19488, 5, Rio Grande do Sul, Triunfo, rio Jacuí basin, rio Taquari at Barreto. MCP 20243, 24, Rio Grande do Sul, lago Guaíba at Barra do Ribeiro. MCP 42644, 2, 1 c\&s, Rio Grande do Sul, Muçum, rio Jacuí basin, rio Taquari at mouth of rio Guaporé. Spatuloricaria sp.: Brazil: MCP 15906, 5, 1 c\&s, Goiás, Uruaçu, rio Tocantins basin, rio Passa Três near Laticínio Gogó. Spatuloricaria tuira: Brazil: MZUSP 94853, 1 c\&s, Mato Grosso, Paranatinga, rio Xingu basin, rio Culuene at Paranatinga 2 hydroelectric powerplant. Sturisoma robustum: Brazil: MCP 15812, 8, 1 c\&s, Mato Grosso, rio Paraguay basin, rio Paraguay at Cáceres. Sturisoma rostratum: Brazil: MCP 36445, 7, 1 c\&s, Rondônia, Ji-Paraná, rio Madeira basin, igarapé do Miolo ca. 15 km NW of Ji-Paraná. MCP 44612, 2, Goiás, Britânia, rio Tocantins basin, rio Vermelho.

\section{Acknowledegements}

We thank the following colleagues for lending material in their care and/or hospitality and technical assistance to the first author during visits to their museums and collections: Carlos Ardila (CAR), David Catania (CAS), Henry Agudelo (CIUA), Alejandro Zuluaga and Alexandra Arango (CPUCO), Kevin Swagel, Mary Anne Rogers, Susan Mochel and Chris Jones (FMNH), Aura Juliana Castellanos, Claudia Medina, Diana Espitia and Fernando Forero (IAvH), Saul Prada and Clara Isabel Molina (MPUJ), Ilana Fichberg and Osvaldo Oyakawa (MZUSP), Helmut Wellendorf (NMW), Sven Kullander and Bodil Kajrup (NRM), Martha Patrícia Ramirez (UIS-T), and Richard Vari and Sandra Raredon (USNM). For sending material from Colombia, taking care of permits and documentation, we are especially grateful to Saul Prada (MPUJ), Aura Juliana Castellanos, Diana Espitia, Claudia Medina, and Carlos DoNascimiento (IAvH), and Alejandro Zuluaga (CP-UCO). We are grateful to Carlos Lucena and Margarete Lucena for continued support at the Laboratory of Ichthyology of MCP. An early version of this work was part of a dissertation submitted by the first author in partial fulfillment of a Master's degree in Zoology at Faculdade de Biociencias, Pontifícia Universidade Católica 
do Rio Grande do Sul (PUCRS), Porto Alegre. Both the latter institution and the Museu de Ciências e Tecnologia da PUCRS, Porto Alegre (MCP) provided work space and logistics for the completion of this study. Thanks are due to Lúcia Rapp Py-Daniel (INPA), Mónica Rodriguez (UFU) and Edson Pereira (MCP) for comments on early stages of this study, and to Rich Vari (USNM) who carefully reviewed the manuscript. Barbara Calegari (MCP) assisted with photographs of the species. AL-B thanks Hernán López-Fernández for hosting and support at the University of Toronto and Royal Ontario Museum (ROM) where some portions of the manuscript were completed. RER thanks William Crampton for support at the University of Central Florida, where this manuscript was partially completed during a sabbatical semester. AL-B was financed by CNPq through a Master's scholarship (process \#132489/20104). RER is partially financed by $\mathrm{CNPq}$ (processes \#305180/2010-0, \#207038/2013-9, and \#306455/2014-5), and Fundação de Amparo à Pesquisa do Estado Rio Grande do Sul - FAPERGS (process \# 11/0936-5).

\section{References}

Alexander, R. McN. 1965. Structure and function in the catfish. Journal of Zoology, 148: 88-152.

Armbruster, J. W. 2004. Phylogenetic relationships of the suckermouth armoured catfishes (Loricariidae) with emphasis on the Hypostominae and the Ancistrinae. Zoological Journal of the Linnean Society, 141: 1-80.

Arratia, G. 1987. Description of the primitive family Diplomystidae (Siluriformes, Teleostei, Pisces): morphology, taxonomy and phylogenetic implications. Bonn Zoologisches Forschungsinstitut und Museum Alexander Koenig, Bonner Zoologische Monographien, 120 p., no. 24.

Arratia, G. 1990. Development and diversity of the suspensorium of Trichomycterids and comparison with Loricarioids (Teleostei: Siluriformes). Journal of Morphology, 205: 193-218.

Bremer, K. 1994. Branch support and tree stability. Cladistics, 10: 295-304.

Chardon, M. 1968. Anatomie comparée de l'appareil de Weber et des structures connexes chez les Siluriformes. Tervurem, Musée Royal de l'Afrique Centrale, 277 p. (Musée Royal de l'Afrique Centrale, Tervurem, Belgique. Annales. Série In-80. Sciences Zoologiques, no. 169).

Covain, R., S. Dray, S. Fisch-Muller \& J. I. Montoya-Burgos. 2008. Assessing phylogenetic dependence of morphological traits using co-inertia prior to investigate character evolution in Loricariinae catfishes. Molecular Phylogenetics and Evolution, 46: 986-1002.

Covain, R. \& S. Fisch-Muller. 2007. The genera of the Neotropical armored catfish subfamily Loricariinae (Siluriformes: Loricariidae): a practical key and synopsis. Zootaxa, 1462: $1-40$.

Covain, R., S. Fisch-Muller, C. Oliveira, J. H. Mol, J. I. MontoyaBurgos \& S. Dray. 2016. Molecular phylogeny of the highly diversified catfish subfamily Loricariinae (Siluriformes, Loricariidae) reveals incongruences with morphological classification. Molecular Phylogenetics and Evolution, 94, part B: 492-517.
Dahl, G. 1971. Los peces del norte de Colombia. Ilustró: Octavio Bernal Solano. Bogotá: Instituto de Desarrollo de los Recursos Naturales Renovables/INDERENA/ Ministerio de Agricultura. Bogotá, 391p., il.

Dahl, G. \& F. Medem. 1964. Informe sobre la fauna acuática del rio Sinú. [Bogotá], Corporación Autónoma Regional de los Valles del Magdalena y del Sinú, Departamento de Investigaciones Ictiológicas y Faunísticas, 160p.

Diogo, R., C. Oliveira \& M. Chardon. 2001. On the homologies of the skeletal components of catfish (Teleostei: Siluriformes) suspensorium. Belgian Journal of Zoology, 131: 93-109.

Eigenmann, C. H. 1912. Some results from an ichthyological reconnaissance of Colombia, South America. Part I. Indiana University Studies, (16) [sic no. 8]: 1-27.

Eigenmann, C. H. 1920a. The fishes of the rivers draining the Western Slope of the Cordillera Occidental of Colombia, rios Atrato, San Juan, Dagua and Patia. Indiana University Studies, 7: 1-19.

Eigenmann, C. H. 1920b. A. The fresh-water fishes of Panama east of longitude $80^{\circ} \mathrm{W}$. B. The Magdalena basin and the horizontal and vertical distribution of its fishes. Indiana University Studies, 7: 1-34

Eigenmann, C. H. 1922. The fishes of western South America, Part I. The fresh-water fishes of Northwestern South America, including Colombia, Panama, and the pacific slopes of Ecuador and Peru, together with an appendix upon the fishes of the Rio Meta in Colombia. Memoirs of the Carnegie Museum, 9: 1-[353].

Eschmeyer, W. N. \& J. D. Fong. 2015. Species of Fishes by family/ subfamily in the Catalog of fishes. Electronic version. San Francisco, CA, California Academy of Sciences. Available from: http://research.calacademy.org/research/ichthyology/ catalog/SpeciesByFamily.asp (8 August 2015).

Ferraris, C. J., Jr. 2003. Subfamily Loricariinae (Armored catfishes). Pp. 330-350. In: Reis, R. E, S. O. Kullander \& C. J. Ferraris, Jr. (Orgs.). Check list of the freshwater fishes of South and Central America. Porto Alegre, Edipucrs.

Ferraris, C. J., Jr. 2007. Checklist of catfishes, recent and fossil (Osteichthyes: Siluriformes), and catalogue of siluriform primary types. Zootaxa, 1418: 1-628.

Fichberg, I. 2008. Relações filogenéticas das espécies do gênero Rineloricaria Bleeker, 1862 (Siluriformes, Loricariidae, Loricariinae). Unpublished Ph. D. Dissertation, Universidade de São Paulo, São Paulo, 148p.

Galvis, G., J. I. Mojica \& M. Camargo. 1997. Peces del Catatumbo. Ilustraciones de peces: Uriel Buitrago. Santafé de Bogotá, Asociación Cravo Norte, $118 \mathrm{p}$.

Goloboff, P. A. 1999. NONA (No Name) ver. 2. Published by the author. Tucumán, Argentina.

Grande, L. 1987. Redescription of †Hypsidoris farsonensis (Teleostei: Siluriformes), with a reassessment of its phylogenetic relationships. Journal of Vertebrate Paleontology, 7: 24-54.

Hennig, W. 1966. Phylogenetic systematics. Translated by Dwight, D. D. \& Zangerl, R. Original: Grundzüge einer Theorie der Phylogenetischen Systematik, 1950. Urbana, University of Illinois Press, 263p.

Howes, G. J. 1983. The cranial muscles of loricarioid catfishes, their homologies and value as taxonomic characters (Teleostei: Siluroidei). Bulletin of the British Museum (Natural History), Zoology series, 45: 309-345.

Ibarra, M. \& D. J. Stewart. 1987. Catalogue of type specimens of recent fishes in Field Museum of Natural History. Fieldiana Zoology (New Series), (35): 1-112. 
International Commission on Zoological Nomenclature (ICZN). 1999. International code of zoological nomenclature $=$ Code international de nomenclature zoologique. $4^{\text {th }}$ ed. London, International Trust for Zoological Nomenclature, Natural History Museum, 306 p.

IUCN Standards and Petitions Subcommittee. 2014. Guidelines fro using the IUCN Red List Categories and Criteria. Version 11. Prepared by the Standards and Petitions Subcommittee. available from http:/www.iucnredlist.org/documents/ RedListGuidelines.pdf (Date of access - 10 March 2016).

Isbrücker, I. J. H. 1979. Description préliminaire de nouveaux taxa de la famille des Loricariidae, poissons-chats cuirassés néotropicaux, avec un catalogue critique de la sousfamille nominale (Pisces, Siluriformes). Revue Française d'Aquariologie et Herpetologie, (5, for 1978): 86-116.

Isbrücker, I. J. H. 1980. Classification and catalogue of the mailed Loricariidae (Pisces, Siluriformes). Verslagen en Technische Gegevens, Instituut voor Taxonomische Zöologie (Zöologisch Museum), Universiteit van Amsterdam, 22: 1-181.

Isbrücker, I. J. H. 1981. Revision of Loricaria Linnaeus, 1758 (Pisces, Siluriformes, Loricariidae). Beaufortia, 31: 51-96.

Lehmann A., P. 2006. Anatomia e relações filogenéticas da família Loricariidae (Ostariophysi: Siluriformes) com ênfase na subfamília Hypoptopomatinae. Unpublished $\mathrm{Ph}$. D. Dissertation, Pontifícia Universidade Católica do Rio Grande do Sul, Porto Alegre, 419 p.

Maddison, W. P. \& D. R. Maddison. 2011. Mesquite: a modular system for evolutionary analysis. Version 2.75. Available from: http://mesquiteproject.org.

Maldonado-Ocampo, J. A., A. Ortega-Lara, J. S. Usma Oviedo, G. Galvis Vergara, F. A. Villa-Navarro, L. Vásquez Gamboa, S. Prada-Pedreros \& C. Ardila-Rodríguez. 2005. Peces de los Andes de Colombia: guía de campo. Ilustrador Juan Cristóbal Calle V. Bogotá, Instituto de Investigación de Recursos Biológicos "Alexander von Humboldt", 346p.

Maldonado-Ocampo, J. A., J. S. Usma Oviedo, F. A. Villa-Navarro, A. Ortega-Lara, S. Prada-Pedreros, L. F. Jiménes, U. JaramilloVilla, A. Arango, T. S. Rivas \& G. C. Sánchez Garcés. 2012. Peces dulceacuícolas del Chocó biogeográfico de Colombia. Colombia, WWF Colombia, Instituto de Investigación de Recursos Biológicos "Alexander von Humboldt" (IAvH), Universidad del Tolima, Autoridad Nacional de Acuicultura y Pesca (AUNAP), Pontificia Universidad Javeriana, 400 p.

Maldonado-Ocampo, J. A., F. A. Villa-Navarro, A. Ortega-Lara, S. Prada-Pedreros, U. Jaramillo-Villa, A. Claro, J. S. Usma, T. S. Rivas Lara, W. Chaverra Salazar, J. F. Cuesta Barrios \& J. E. García-Melo. 2006. Peces del río Atrato, zona hidrogeográfica del Caribe, Colombia. Biota Colombiana, 7: 143-154.

Meek, S. E. \& S. F. Hildebrand. 1913. New species of fishes from Panama. Field Museum of Natural History Publications Zoölogical Series, 10: 77-91.

Meek, S. E. \& S. F. Hildebrand. 1916. The fishes of the fresh waters of Panama. Field Museum of Natural History Publications Zoölogical Series, 10: 1-374, plates 6-32.

Miles, C. W. 1947. Los peces del Río Magdalena. A field book of Magdalena fishes. Bogotá, Editorial El Gráfico, 214 p.

Mo, T. 1991. Anatomy, relationships and systematics of the Bagridae (Teleostei: Siluroidei) with a hypothesis of siluroid phylogeny. Königstein, Koeltz Scientific Books, 216p.

Müller, S. \& C. Weber. 1992. Les dents des sous-familles Hypostominae et Ancistrinae (Pisces, Siluriformes, Loricariidae) et leur valeur taxonomique. Revue Suisse de
Zoologie, Annales de la Société Suisse de Zoologie et du Muséum d'Histoire Naturelle de Genève, 99: 747-754.

Nixon, K. C. 2002. WinClada ver. 1.00.08. Published by the author: Ithaca, NY, USA. Cladistics, 15: 407-414.

Paixão, A. C. \& M. Toledo-Piza. 2009. Systematics of Lamontichthys Miranda-Ribeiro (Siluriformes: Loricariidae), with the description of two new species. Neotropical Ichthyology, 7: 519-568.

Pereira, E. H. L. 2008. Relações filogenéticas de Neoplecostominae Regan, 1904 (Siluriformes: Loricariidae). Unpublished Ph. D. Dissertation, Pontifícia Universidade Católica do Rio Grande do Sul, Porto Alegre, $260 \mathrm{p}$.

Pinna, M. C. C. de. 1993. Higher-level phylogeny of Siluriformes, with a new classification of the order (Teleostei, Ostariophysi). Unpublished Ph. D. Dissertation, City University of New York, New York, 482p.

Provenzano, F. 2011. Estudio sobre las relaciones filogenéticas de las especies incluidas en la subfamilia Loricariinae (Siluriformes, Loricariidae). Unpublished Ph. D. Dissertation, Universidad Central de Venezuela, Caracas, 275p.

Rapp Py-Daniel, L. H. 1997. Phylogeny of the Neotropical armored catfishes of the subfamily Loricariinae (Siluriformes: Loricariidae). Unpublished Ph. D. Dissertation, University of Arizona, Tucson, 280p.

Reis, R. E. 1998. Anatomy and phylogenetic analysis of the Neotropical callichthyid catfishes (Ostariophysi, Siluriformes). Zoological Journal of the Linnean Society, 124: 105-168.

Reis, R. E. \& E. H. L. Pereira. 2000. Three new species of the loricariid catfish genus Loricariichthys (Teleostei: Siluriformes) from southern South America. Copeia, 2000(4): 1029-1047.

Rodriguez, M. S., H. Ortega \& R. Covain. 2011. Intergeneric phylogenetic relationships in catfishes of the Loricariinae (Siluriformes: Loricariidae), with the description of Fonchiiloricaria nanodon: a new genus and species from Peru. Journal of Fish Biology, 79: 875-895.

Rodriguez, M. S. \& R. E. Reis. 2008. Taxonomic review of Rineloricaria (Loricariidae: Loricariinae) from the Laguna dos Patos drainage, southern Brazil, with the descriptions of two new species and the recognition of two species groups. Copeia, 2008(2): 333-349.

Rodríguez-Olarte, D., J. I. Mojica Corzo \& D. C. T. Baechle. 2011. Northern South America: Magdalena and Maracaibo Basins. Pp. 243-258. In: Albert, J. S. \& Reis, R. E. (Eds.). Historical biogeography of neotropical freshwater fishes. Berkeley \& Los Angeles, University of California Press.

Sabaj Pérez, M. H. 2012. Standard symbolic codes for institutional resource collections in herpetology and ichthyology: an Online Reference. Version 3.0. Available from: http://www.asih. org/, American Society of Ichthyologists and Herpetologists, Washington, DC. (8 August 2015).

Schaefer, S. A. 1987. Osteology of Hypostomus plecostomus (Linnaeus), with a phylogenetic analysis of the loricariid subfamilies (Pisces: Siluroidei). Contributions in Science, Natural History Museum of Los Angeles County, 394: 1-31.

Schaefer, S. A. 1990. Anatomy and relationships of the Scoloplacid catfishes. Proceedings of the Academy of Natural Sciences of Philadelphia, 142: 167-210.

Schaefer, S. A. 1991. Phylogenetic analysis of the loricariid subfamily Hypoptopomatinae (Pisces: Siluroidei: Loricariidae), with comments on generic diagnoses and geographic distribution. Zoological Journal of the Linnean Society, 102: 1-41. 
Schaefer, S. A. 1997. The Neotropical cascudinhos: systematics and biogeography of the Otocinclus catfishes (Siluriformes: Loricariidae). Proceedings of the Academy of Natural Sciences of Philadelphia, 148: 1-120.

Schaefer, S. 2011. The Andes: Riding the tectonic uplift. Pp. 259-278. In: Albert, J. S. \& Reis, R. E. (Eds.). Historical biogeography of Neotropical freshwater fishes. Berkeley \& Los Angeles, University of California Press.

Schaefer, S. A. \& G. V. Lauder. 1986. Historical transformation of functional design: evolutionary morphology of feeding mechanisms in Loricarioid catfishes. Systematic Zoology, 35 : 489-508.

Schultz, L. P. 1944. The catfishes of Venezuela, with descriptions of thirty-eight new forms. Proceedings of the United States National Museum, 94: 173-338.

Shelden, F. F. 1937. Osteology, myology and probable evolution of the nematognath pelvic girdle. Annals of the New York Academy of Sciences, 37: 1-96.

Steindachner, F. 1878. Zur Fisch-fauna des MagdalenenStromes. Denkschriften der Kaiserlichen Akademie der Wissenschaften Mathematisch-Naturwissenschaftliche, Wien Classe, 39: 19-78.
Taylor, W. R. \& G. C. Van Dyke. 1985. Revised procedures for staining and clearing small fishes and other vertebrates for bone and cartilage study. Cybium, 9: 107-119.

Thomas, M. R. \& L. H. Rapp Py-Daniel. 2008. Three new species of the armored catfish genus Loricaria (Siluriformes: Loricariidae) from river channels of the Amazon basin. Neotropical Ichthyology, 6: 379-394.

Villa-Navarro, F. A., P. T. Zúñiga-Upegui, D. Castro-Roa, J. E. García-Melo, L. J. García-Melo \& M. E. Herrada-Yara. 2006. Peces del alto Magdalena, cuenca del río Magdalena, Colombia. Biota Colombiana, 7: 3-21.

\section{APPENDIX I - Character state matrix}

Data matrix used for the parsimony analysis. A = polymorphic for 1 and 2.

\section{Harttia loricariformis}

0000000000000000000000000000000000000000000000000000000000000000000000 0-00

Sturisoma rostratum

10101000000010203000000000011201001001300000010100102110000200000000001000

Sturisoma robustum

10001000000010203000000000011201001001300000010100002110000200000000001000

Loricariichthys anus

21130220103110101132102000011012220112101100021111101111110200220030001001

Hemiodontichthys acipenserinus

$2112020322311041213212200100101210323120001102112100210110042042003-101001$

Pseudoloricaria laeviuscula

11120200102110312121011000111001220230000110001121211110110322020020001201

Pseudohemiodon sp.

21030010110110301112122001100011200201103231101121212110121331321020001001

Loricaria cataphracta

11120200100110303121113000011002203232203231100121212110111231321022001000

Loricaria clavipinna

11020200101111211121113000011002203232203231100121212110111231321022001000

Ixinandria steinbachi

$10020103100100403110113000111001203031302001001101101020100010400010010-00$

Rineloricaria microlepidogaster

01020101111111222112112010111001003230003021001121102120100110410021111001

Rineloricaria strigilata

21020101111110222112111010111011003200102021001111102110100110010021111001

Spatuloricaria sp.

1101010211 2111A21111 $112010111001010001103231101021212110110210120022110-01$

Spatuloricaria tuira

1102 ?12111 $2111421111100000111102112131003231111121 \quad 2-2110110210120022110-01$

Dasyloricaria filamentosa

11021002222111421112113102111000112122011102001121112210100310110120101011

Dasyloricaria paucisquama

11020112222111421112113102111000112122011102001121112210100310110120101011

Dasyloricaria latiura

11021002222111421112213102111000112122011102001121112210100310110120101111 


\section{Appendix II - Character-state transformations}

Character-state transformations by clade with only unambiguous changes listed except for node 1 , in which transformations are presented under ACCTRAN optimization. Transformations are listed with the character number first and then the plesiomorphic $>$ apomorphic state. Transformations listed in bold are exclusive synapomorphies.

\begin{tabular}{|c|c|}
\hline Node 1 & Node 8 \\
\hline $10>1$ & $410>3$ \\
\hline $130>1$ & $450>1$ \\
\hline $150>2$ & $590>1$ \\
\hline $170>3$ & $612>3$ \\
\hline $280>1$ & $650>1$ \\
\hline \multicolumn{2}{|l|}{$290>1$} \\
\hline $320>1$ & Node 9 (Loricaria) \\
\hline $350>1$ & $232>3$ \\
\hline $380>1$ & $271>0$ \\
\hline $390>3$ & $321>2$ \\
\hline $480>1$ & $381>2$ \\
\hline $510>1$ & $471>0$ \\
\hline $530>2$ & $680>2$ \\
\hline $540>1$ & $741>0$ \\
\hline \multicolumn{2}{|l|}{$550>1$} \\
\hline $600>2$ & Node 10 \\
\hline \multirow[t]{2}{*}{$710>1$} & $100>1$ \\
\hline & $160>2$ \\
\hline Node 2 (Sturisoma) & $410>3$ \\
\hline $50>1$ & $690>1$ \\
\hline \multicolumn{2}{|l|}{$300>2$} \\
\hline \multirow[t]{2}{*}{$460>1$} & Node 11 (Rineloricaria) \\
\hline & $154>2$ \\
\hline Node 3 (Loricariini) & $250>1$ \\
\hline $40>2$ & $381>0$ \\
\hline $60>1$ & $430>2$ \\
\hline $90>1$ & $602>1$ \\
\hline $120>1$ & $680>1$ \\
\hline \multicolumn{2}{|l|}{$180>1$} \\
\hline $190>1$ & Node 12 \\
\hline $210>1$ & $340>1$ \\
\hline $220>1$ & $362>1$ \\
\hline $270>1$ & $520>1$ \\
\hline $370>3$ & $630>1$ \\
\hline \multicolumn{2}{|l|}{$440>1$} \\
\hline $470>1$ & Node 13 (Spatuloricaria) \\
\hline $500>1$ & $202>1$ \\
\hline $570>1$ & $430>3$ \\
\hline \multirow[t]{2}{*}{$610>1$} & $450>1$ \\
\hline & $511>2$ \\
\hline Node 4 & $580>1$ \\
\hline $20>1$ & $680>2$ \\
\hline $173>1$ & $711>0$ \\
\hline \multicolumn{2}{|l|}{$200>2$} \\
\hline $360>2$ & Node 14 (Dasyloricaria) \\
\hline $490>2$ & $91>2$ \\
\hline \multirow[t]{2}{*}{$740>1$} & $101>2$ \\
\hline & $232>3$ \\
\hline Node 5 & $240>1$ \\
\hline $61>2$ & $260>2$ \\
\hline \multirow[t]{2}{*}{$611>2$} & $321>0$ \\
\hline & $373>2$ \\
\hline Node 6 & $381>2$ \\
\hline $11>2$ & $400>1$ \\
\hline $110>3$ & $413>1$ \\
\hline $271>0$ & $441>2$ \\
\hline $310>1$ & $541>2$ \\
\hline $321>2$ & $660>1$ \\
\hline $460>2$ & $730>1$ \\
\hline \multicolumn{2}{|l|}{$560>1$} \\
\hline $672>3$ & $\begin{array}{l}\text { Node } 15 \text { (D. filamentosa }+ \text { D. latiura) } \\
50>1\end{array}$ \\
\hline Node 7 & $61>0$ \\
\hline $154>3$ & \\
\hline $511>2$ & \\
\hline $520>1$ & \\
\hline
\end{tabular}

